Radionuclide Contaminant Analysis of Small Mammals at Area G, TA-54, 1994

James Biggs

Kathy Bennett

Phil Fresquez 


\section{DISCLAIMER}

This document was prepared as an account of work sponsored by an agency of the United States Government. Neither the United States Government nor the University of California nor any of their employees, makes any warranty, express or implied, or assumes any legal liability or responsibility for the accuracy, completeness, or usefuiness of any information, apparatus, product, or process disclosed, or represents that its use would not infringe privately owned rights. Reference herein to any specific commercial product, process, or service by trade name, trademark, manufacturer, or otherwise, does not necessarily constitute or imply its endorsement, recommendation, or favoring by the United States Government or the University of California. The views and opinions of authors expressed herein do not necessarily state or reflect those of the United States Government or the University of California, and shall not be used for advertising or product endorsement purposes. 


\section{DISCLAIMER}

Portions of this document may be illegible in electronic image products. Images are produced from the best available original document. 


\title{
RADIONUCLIDE CONTAMINANT ANALYSIS OF SMALL MAMMALS AT AREA G, TA-54, 1994
}

\author{
by \\ James Biggs, Kathy Bennett, and Phil Fresquez
}

\begin{abstract}
Small mammals were sampled at two waste burial sites (1 and 2) at Area G, TA-54 and a control site outside Area $\mathbf{G}$ (Site 3) to identify radionuclides that are present within surface and subsurface soils at waste burial sites, to compare the amount of radionuclide uptake by small mammals at waste burial sites to a control site, and to identify the primary mode of contamination to small mammals, either through surface contact or ingestion/inhalation. Three composite samples of at least five animals per sample were collected at each site. Pelts and carcasses of each animal were separated and analyzed independently. Samples were analyzed for ${ }^{241} \mathrm{Am},{ }^{90} \mathrm{Sr},{ }^{238} \mathrm{Pu},{ }^{239} \mathrm{Pu}$, total $\mathrm{U}$, and gamma spectroscopy (including ${ }^{137} \mathrm{Cs}$ ). Significantly higher (parametric t-test at $\mathrm{p}=0.05$ ) levels of total $\mathrm{U},{ }^{241} \mathrm{Am},{ }^{238} \mathrm{Pu},{ }^{239} \mathrm{Pu}$, and ${ }^{40} \mathrm{~K}$ were detected in pelts as compared to the carcasses of small mammals at TA-54. Concentrations of other measured radionuclides in carcasses were nearly equal to or exceeded the mean concentrations in the pelts. Our results show higher concentrations in pelts compared to carcasses which is similar to what has been found at waste burial/contaminated sites outside of Los Alamos National Laboratory. Site 1 had significantly higher (alpha $=0.05$, $F=0.0095$ ) total $U$ concentrations in carcasses than Sites 2 and 3. Site 2 had significantly higher (alpha $=0.05, F=0.0195$ ) ${ }^{239} \mathrm{Pu}$ concentrations in carcasses than either Site 1 or Site 3. A significant difference in ${ }^{90} \mathrm{Sr}$ concentration existed between Sites 1 and 2 (alpha $=0.05$, $F=0.0681$ ) and concentrations of ${ }^{40} \mathrm{~K}$ at Site 1 were significantly different from Site 3 .
\end{abstract}

\section{INTRODUCTION}

A solid, low-level radioactive disposal facility has been operating at Area G, TA-54 since 1957 and has been used to dispose of various wastes including tritium waste, transuranic waste, volatile organic compounds, and mixed waste. Environmental monitoring of air, soil, water runoff, and vegetation has been in place to examine potential migration of contaminants. Recently, there has been no sampling to determine contaminant concentration of small mammals within the boundaries of Area G. Consequently, the collection and analysis of small mammals at TA-54, Area G, was 
initiated as part of the Enhanced Environmental Annual Surveillance program at Area $G$ by the Environmental, Safety, and Health Division in collaboration with the Solid Waste Management Group. The program is intended to provide data to aid in meeting requirements of DOE Order 5400.1 , which specifies monitoring of existing operations at radioactive waste burial sites.

Rodents can affect the distribution of radionuclides at radioactive waste burial sites through their burrowing activities (Arthur et.al. 1987). Burrowing activity and mound building can expose contaminated soils which can then be dispersed by wind and water erosion (Winsor and Whicker 1980). Predators of small mammals can also disperse radioactive material in their feces, urine, or regurgitated pellets (Eisler 1994). Burrowing animals can also alter the soil profile and change the physical and chemical processes in the soil profile resulting in movements of buried contaminants (Hakonson et.al. 1982). In addition, small mammals utilizing waste burial sites can be contaminated through direct contact of contaminated soil or by ingestion of soil (i.e., soil consumption during pelt grooming) or from foraging on plant resources (O'Farrell and Gilbert 1975) and could subsequently become a form of contaminant transport off site via predation from predator species (Craig et.al. 1979).

The collection and analysis of burrowing, small mammals at two waste burial sites (Sites 1 and 2) within Area G, TA-54, Los Alamos National Laboratory, were used to 1) identify radionuclides potentially present within surface and subsurface soils at waste burial sites within Area $\mathrm{G}$ by sampling of burrowing, nocturnal small mammal tissues, 2) quantitatively estimate and compare the amount of radionuclide uptake at specific waste burial sites within Area $G$ to a control site (Site 3) by sampling carcasses of burrowing, nocturnal small mammals, 3) determine the primary mode of contamination to small mammals, either by surface contact or through ingestion, and 4) estimate small mammal densities at each waste burial site and the control site for use in estimating potential contaminant loads within the rodent population. Data collected from the waste burial 
sites was compared to a control site. A general description of Area $\mathrm{G}$ and the various wastes buried within its boundaries is given in Eklund (1995).

\section{METHODOLOGY}

Three sites were selected for sampling (trapping) within Area G (Figure 1) with respect to ongoing disposal operations. These sites were defined as follows:

1) Recently disturbed/contaminated site: a shallow earth-covered transuranic uranium drum storage site built on top of old previously filled disposal pits; vegetation not well established and consists of plant species associated with disturbed ground.

2) Partially disturbed/contaminated waste burial site: this site has established vegetation with a mixture of native plants and plant species associated with disturbed ground.

3) Control site, undisturbed/uncontaminated: no waste operations occurring at this site; consists of well-established native plant species associated with a piñon pine/juniper woodland

Site 1 is located on a recent waste storage earthen mound with a lack of well established vegetation, Site 2 was located on a waste burial site where vegetation has become well established, and Site 3 is located west of the check-in facility for Area G. Site 3, located within a piñon-juniper woodland and adjacent to the operating disposal site, was selected as the control site. Vegetation samples were also collected at various locations within and near Area $G$ waste burial sites (Fresquez, et.al. 1995), including two locations at Site 1 of the small mammal sampling areas. When applicable, results of vegetation sampling are presented in the text of this report.

A grid design consisting of 100 snap traps placed approximately $10 \mathrm{~m}$ apart in a $10 \times 10$ design was used to collect animals at each of the three sites. Snap trapping took place over 3 to 4 nights 


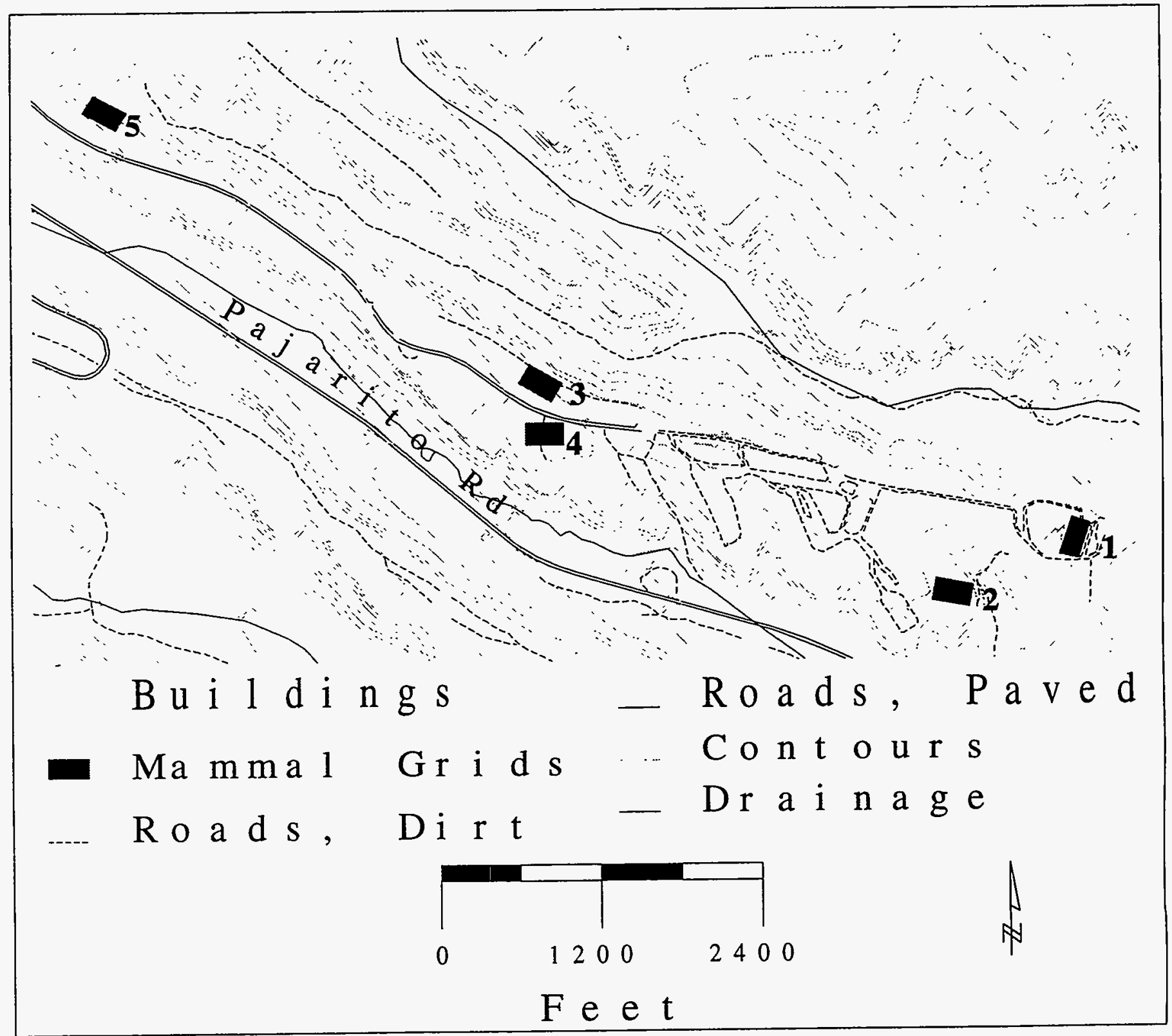

Figure 1. Locations of $\mathrm{sit}$ e $\mathrm{s}$ of $\mathrm{smal}$ l mammal grids a $\mathrm{t}$ Area $\mathrm{G}$. ( $\mathrm{Sites} 4$ and 5 were 1 ater added because of low capture rates at $\mathrm{Site} 3$.) 
(until at least 15 animals were captured at each site). Procedures for handling and field processing of small mammals with respect to potential infection of hantavirus, are given in Mills, et.al, and Biggs and Bennett. These same safety procedures were followed for collecting tissue samples from snap-trapped animals. At least 15 rodents were captured at Sites 1 and 2. However, low capture rates at Site 3 necessitated additional sampling in the vicinity of that location (identified as Sites 4 and 5 on Figure 1). Additional snap traps were placed in similar habitat adjacent to Site 3 and west of the Area $G$ controlled access gate to ensure that a sufficient sample size was obtained for analysis. Snap traps were baited and set in late afternoon and checked in early morning. Traps with animals were taken to a central processing station where pelts were removed. Precautions during handling were taken to minimize cross contamination from carcass to pelt while removing pelts. All external hair was removed from appendages.

Three (3) composite samples were collected at each site with each sample consisting of a minimum 5 animals. The pelt was separated from the carcass of each animal and analysis was run on the pelt and carcass separately for each radionuclide. Due to total ashed weight, the three composite samples of pelts were combined for each site for a total of one sample per site only. The samples were placed into 1-L glass beakers. The beaker contents were covered with tin foil and ashed at $500^{\circ} \mathrm{C}$ for $120 \mathrm{hr}$. The sample ash was pulverized and homogenized before it was submitted to a LANL analytical laboratory for the analysis of ${ }^{241} \mathrm{Am},{ }^{90} \mathrm{Sr},{ }^{238} \mathrm{Pu},{ }^{239} \mathrm{Pu}$, total $\mathrm{U}$, gamma spectropscopy (including ${ }^{137} \mathrm{Cs}$ ). All methods of radiochemical analysis have been described previously (Salazar 1984). Results are reported on a per ash weight basis (g/ash). There were insufficient amounts of pelts to analyze the composite samples separately due to a minimum amount of ash required to conduct the analysis. In these cases, the composite samples were combined for each site. Analysis of pelts and carcasses separately allowed for a more accurate determination of radionuclide concentration (ingestion/inhalation or external body surface). 
The Statistical Analysis System (SAS) was used to analyze all data sets (SAS/STAT User's Guide 1988). A univariate test was used to determine if carcass radionuclide means were normally distributed within each site. Most means were normally distributed, therefore a parametric t-test was used to determine if the means of each radionuclide were equal between carcasses and pelts. This was not conducted by site since only one pelt sample per site existed. An Analysis of Variance (ANOVA) was used to determine if any significant differences in the amount of radionuclide in carcass samples existed between sites (the ANOVA generates an alpha [probability] at the 0.05 level) and Duncan's multiple range test was used to identify where the significant differences occurred between the sites.

Rodent densities were estimated using Leslie's regression method (Seber 1982) applied to each grid where daily total number of captures were plotted against the cumulative daily captures.

Confidence intervals were calculated at $90 \%$ using the general method (Seber 1982).

\section{RESULTS}

\section{Density Estimates}

Deer mice (Peromyscus maniculatus) was the only small mammal species captured at Sites 1 and 2. Deer mice and pinyon mice ( $P$. trueii) were captured at the control site. The highest densities of animals occurred on Sites 1 and 2 with very low capture rates at the control site. Because of the low capture rates at Site 3, additional locations were trapped adjacent to it. Density estimates of rodents occurring at Sites 1 and 2 were calculated by regressing the number of daily captures onto the cumulative number of captures for each day. Rodent density of Site 3 is based on total number of animals captured due to no new captures being recorded on the last day of trapping. The density of the trapping area is based on a $100 \mathrm{~m}$ by $100 \mathrm{~m}$ grid with an additional $5 \mathrm{~m}$ boundary strip to help account for animals being drawn into the grid due to the bait. Therefore the total effective trapping area is approximately 1.21 ha. Table 1 gives the estimated density (\# animals/ha) of each site sampled after adjustment for the total effective trapping area. 
Table 1. Rodent Density Estimate of Area G (Sites 1 and 2) and Control (Site 3).

\begin{tabular}{|c|c|c|c|}
\hline SITE 1 & DAY & NO. OF CAPTURES & NO. OF TRAPS \\
\hline & 1 & 13 & 100 \\
\hline & 2 & 6 & 100 \\
\hline & 3 & 5 & 100 \\
\hline $\begin{array}{l}\text { DENSITY ESTIMATE (\# animals/ } \\
\text { ha) }\end{array}$ & \multicolumn{3}{|l|}{23.84} \\
\hline VAR(N) ESTIMATE & \multicolumn{3}{|l|}{13.24} \\
\hline $90 \%$ CONFIDENCE INTERVAL & \multicolumn{2}{|c|}{$\begin{array}{l}\text { Lower 90\% Limit } \\
4.08\end{array}$} & $\begin{array}{l}\text { per 90\% Limit } \\
61.85\end{array}$ \\
\hline
\end{tabular}

\begin{tabular}{|c|c|c|c|}
\hline SITE 2 & DAY & NO. OF CAPTURES & NO. OF TRAPS \\
\hline & 1 & 17 & 100 \\
\hline & 2 & 6 & 100 \\
\hline & 3 & 1 & 100 \\
\hline $\begin{array}{l}\text { DENSITY ESTIMATE (\# animals/ } \\
\text { ha }\end{array}$ & \multicolumn{3}{|l|}{20.67} \\
\hline VAR(N) ESTIMATE & \multicolumn{3}{|l|}{0.60} \\
\hline 90\% CONFIDENCE INTERVAL & \multicolumn{2}{|c|}{$\begin{array}{l}\text { Lower 90\% Limit } \\
17.09\end{array}$} & $\begin{array}{l}\text { per } 90 \% \text { Limit } \\
27.04\end{array}$ \\
\hline
\end{tabular}

\begin{tabular}{|l|l|l|l|}
\hline SITE 3 & DAY & NO. OF CAPTURES & $\begin{array}{l}\text { NO. OF } \\
\text { TRAPS }\end{array}$ \\
\hline & 1 & 4 & 100 \\
\hline & 2 & 0 & 100 \\
\hline & 3 & - & - \\
\hline $\begin{array}{c}\text { DENSITY ESTIMATE (\# animals/ } \\
\text { ha) }\end{array}$ & $3.31^{*}$ & & \\
\hline
\end{tabular}

* no new captures were recorded after the first night of trapping, therefore, a third night of trapping was not conducted; this estimate is treated as a "complete census" of rodents at the site.

\section{Radionuclide Analysis}

Results of data analysis presented in this paper are primarily for the radionuclides total $U,{ }^{241} \mathrm{Am}$, ${ }^{238} \mathrm{Pu}$ and ${ }^{239} \mathrm{Pu},{ }^{90} \mathrm{Sr},{ }^{137} \mathrm{Cs}, \mathrm{Bi}^{214},{ }^{60} \mathrm{Co},{ }^{152} \mathrm{Eu},{ }^{40} \mathrm{~K}$, and ${ }^{208} \mathrm{Tl}$ (Table 2). A total of 27 radionuclides were analyzed using gamma spectroscopy. However, results are presented only for those that showed detectable activity based on the gamma spectroscopy. These included ${ }^{137} \mathrm{Cs},{ }^{214} \mathrm{Bi},{ }^{60} \mathrm{Co}$, ${ }^{152} \mathrm{Eu},{ }^{40} \mathrm{~K}$, and ${ }^{208} \mathrm{TI}$. A complete list of radionuclides analyzed and the analytical results are given in Appendix A. 
Table 2. Summary of Analytical Results for Radionuclides Showing Detectable Activity.

\begin{tabular}{|c|c|c|c|c|c|}
\hline SITE & $\begin{array}{l}\text { SAMPLE } \\
\text { NUMBER }\end{array}$ & RADIOISOTOPE & SAMPLE TYPE & $\begin{array}{l}\text { ANALYTICAL } \\
\text { RESULT }(\mu \mathrm{g} / \mathrm{g} \text { or } \\
\mathrm{pCi} / \mathrm{g})^{1}\end{array}$ & $\begin{array}{l}\text { ANALYTICAL } \\
\text { UNCERTAINTY }\end{array}$ \\
\hline 1 & 1 & ${ }^{2+1} \mathrm{Am}$ & Carcass & 0.01 & 0.03 \\
\hline 1 & 2 & ${ }^{241} \mathrm{Am}$ & Carcass & 0.009 & 0.03 \\
\hline 1 & 3 & ${ }^{241} \mathrm{Am}$ & Carcass & 0.012 & 0.03 \\
\hline 1 & 1 & ${ }^{241} \mathrm{Am}$ & Pelt & 0.052 & 0.03 \\
\hline 1 & 1 & ${ }^{238} \mathrm{Pu}$ & Carcass & 0.137 & 0.031 \\
\hline 1 & 2 & ${ }^{238} \mathrm{Pu}$ & Carcass & 0.173 & 0.037 \\
\hline 1 & 3 & ${ }^{238} \mathrm{Pu}$ & Carcass & 0.012 & 0.03 \\
\hline 1 & 1 & ${ }^{238} \mathrm{Pu}$ & Pelt & 0.506 & 0.035 \\
\hline 1 & 1 & ${ }^{239} \mathrm{Pu}$ & Carcass & 0.034 & 0.02 \\
\hline 1 & 2 & ${ }^{239} \mathrm{Pu}$ & Carcass & 0.023 & 0.015 \\
\hline 1 & 3 & ${ }^{239} \mathrm{Pu}$ & Carcass & 0.02 & 0.02 \\
\hline 1 & 1 & ${ }^{239} \mathrm{Pu}$ & Peit & 0.089 & 0.02 \\
\hline 1 & 1 & ${ }^{90} \mathrm{Sr}$ & Carcass & 1.7 & 0.2 \\
\hline 1 & 2 & ${ }^{90} \mathrm{Sr}$ & Carcass & 3.4 & 0.2 \\
\hline 1 & 3 & ${ }^{90} \mathrm{Sr}$ & Carcass & 2.8 & 0.3 \\
\hline 1 & 1 & ${ }^{90} \mathrm{Sr}$ & Pelt & 0.9 & 0.5 \\
\hline 1 & 1 & ${ }^{137} \mathrm{Cs}$ & Carcass & 0.04 & 0.06 \\
\hline 1 & 2 & ${ }^{137} \mathrm{Cs}$ & Carcass & 0.04 & 0.06 \\
\hline 1 & 3 & ${ }^{137} \mathrm{Cs}$ & Carcass & 0.04 & 0.06 \\
\hline 1 & 1 & ${ }^{137} \mathrm{Cs}$ & Pelt & 0.02 & 0.03 \\
\hline 1 & 1 & ${ }^{214} \mathrm{Bi}$ & Carcass & $\overline{0.41}$ & 0.13 \\
\hline 1 & 2 & ${ }^{214} \mathrm{Bi}$ & Carcass & 0.72 & 0.16 \\
\hline 1 & 3 & ${ }^{214} \mathrm{Bi}$ & Carcass & 0.58 & 0.15 \\
\hline 1 & 1 & ${ }^{214} \mathrm{Bi}$ & Pelt & 0.42 & 0.14 \\
\hline 1 & 1 & ${ }^{60} \mathrm{Co}$ & Carcass & $\overline{0.94}$ & 0.17 \\
\hline 1 & 2 & ${ }^{60} \mathrm{Co}$ & Carcass & 1.01 & 0.15 \\
\hline 1 & 3 & ${ }^{80} \mathrm{Co}$ & Carcass & 1.12 & 0.16 \\
\hline 1 & 1 & ${ }^{80} \mathrm{Co}$ & Pelt & 0.99 & 0.15 \\
\hline 1 & 1 & ${ }^{152} \mathrm{Eu}$ & Carcass & 2.24 & 0.55 \\
\hline 1 & 2 & ${ }^{152} \mathrm{Eu}$ & Carcass & 2.36 & 0.56 \\
\hline 1 & 3 & ${ }^{152} \mathrm{Eu}$ & Carcass & 2.66 & 0.63 \\
\hline 1 & 1 & ${ }^{152} \mathrm{Eu}$ & Pelt & 1.97 & 0.52 \\
\hline 1 & 1 & ${ }^{40} \mathrm{~K}$ & Carcass & 50.15 & 5.78 \\
\hline
\end{tabular}


Table 2 (cont.).

\begin{tabular}{|c|c|c|c|c|c|}
\hline SITE & $\begin{array}{l}\text { SAMPLE } \\
\text { NUMBER }\end{array}$ & RADIOISOTOPE & SAMPLE TYPE & $\begin{array}{c}\text { ANALYTICAL } \\
\text { RESULT }(\mu \mathrm{g} / \mathrm{g} \text { or } \\
\mathrm{pCi} / \mathrm{g})^{1}\end{array}$ & $\begin{array}{l}\text { ANALYTICAL } \\
\text { UNCERTAINTY }\end{array}$ \\
\hline 1 & 2 & ${ }^{40} \mathrm{~K}$ & Carcass & 49.47 & 5.73 \\
\hline 1 & 3 & ${ }^{40} \mathrm{~K}$ & Carcass & 47.19 & 5.5 \\
\hline 1 & 1 & ${ }^{40} \mathrm{~K}$ & Pelt & 43.45 & 5.14 \\
\hline 1 & 1 & ${ }^{208} \mathrm{Tl}$ & Carcass & 0.22 & 0.07 \\
\hline 1 & 2 & ${ }^{208} \mathrm{Tl}$ & Carcass & 0.25 & 0.06 \\
\hline 1 & 3 & ${ }^{208} \mathrm{Tl}$ & Carcass & 0.26 & 0.07 \\
\hline 1 & 1 & ${ }^{208} \mathrm{Tl}$ & Pelt & 0.26 & 0.07 \\
\hline 2 & 1 & total U & Carcass & 0.318 & 0.032 \\
\hline 2 & 2 & total U & Carcass & 0.397 & 0.040 \\
\hline 2 & 3 & total U & Carcass & 0.316 & 0.038 \\
\hline 2 & 1 & total U & Pelt & 1.362 & 0.136 \\
\hline 2 & 1 & ${ }^{241} \mathrm{Am}$ & Carcass & 0.099 & 0.030 \\
\hline 2 & 2 & 241 $\mathrm{Am}$ & Carcass & 0.034 & 0.030 \\
\hline 2 & 3 & ${ }^{241} \mathrm{Am}$ & Carcass & 0.019 & 0.030 \\
\hline 2 & 1 & ${ }^{2+1} \mathrm{Am}$ & Pelt & 1.14 & 0.071 \\
\hline 2 & 1 & ${ }^{238} \mathrm{Pu}$ & Carcass & 0.033 & 0.010 \\
\hline 2 & 2 & ${ }^{238} \mathrm{Pu}$ & Carcass & 0.001 & 0.004 \\
\hline 2 & 3 & ${ }^{238} \mathrm{Pu}$ & Carcass & 0.006 & 0.002 \\
\hline 2 & 1 & ${ }^{238} \mathrm{Pu}$ & Pelt & 0.237 & 0.030 \\
\hline 2 & 1 & ${ }^{239} \mathrm{Pu}$ & Carcass & 0.121 & 0.017 \\
\hline 2 & 2 & ${ }^{239} \mathrm{Pu}$ & Carcass & 0.072 & 0.010 \\
\hline 2 & 3 & ${ }^{239} \mathrm{Pu}$ & Carcass & 0.042 & 0.006 \\
\hline 2 & 1 & ${ }^{239} \mathrm{Pu}$ & Pelt & 1.269 & 0.079 \\
\hline 2 & 1 & ${ }^{90} \mathrm{Sr}$ & Carcass & 1.7 & 0.2 \\
\hline 2 & 2 & ${ }^{90} \mathrm{Sr}$ & Carcass & 0.6 & 0.2 \\
\hline 2 & 3 & ${ }^{90} \mathrm{Sr}$ & Carcass & 1.3 & 0.2 \\
\hline 2 & 1 & ${ }^{90} \mathrm{Sr}$ & Carcass & 1.3 & 0.8 \\
\hline 2 & 1 & ${ }^{137} \mathrm{Cs}$ & Carcass & 0.01 & 0.02 \\
\hline 2 & 2 & ${ }^{137} \mathrm{Cs}$ & Carcass & 0.03 & 0.05 \\
\hline 2 & 3 & ${ }^{137} \mathrm{Cs}$ & Carcass & 0.06 & 0.09 \\
\hline 2 & 1 & ${ }^{137} \mathrm{Cs}$ & Pelt & 0.03 & 0.05 \\
\hline 2 & 1 & ${ }^{214} \mathrm{Bi}$ & Carcass & 0.49 & 0.12 \\
\hline 2 & 2 & ${ }^{214} \mathrm{Bi}$ & Carcass & 0.41 & 0.11 \\
\hline 2 & 3 & ${ }^{214} \mathrm{Bi}$ & Carcass & 0.50 & 0.14 \\
\hline 2 & 1 & ${ }^{214} \mathrm{Bi}$ & Pelt & 0.44 & 0.13 \\
\hline
\end{tabular}


Table 2 (cont.).

\begin{tabular}{|c|c|c|c|c|c|}
\hline SITE & $\begin{array}{l}\text { SAMPLE } \\
\text { NUMBER }\end{array}$ & RADIOISOTOPE & SAMPLE TYPE & 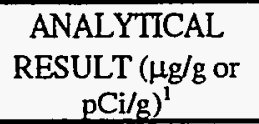 & $\begin{array}{l}\text { ANALYTICAL } \\
\text { UNCERTAINTY }\end{array}$ \\
\hline 2 & 1 & ${ }^{60} \mathrm{Co}$ & Carcass & 0.94 & 0.12 \\
\hline 2 & 2 & ${ }^{60} \mathrm{Co}$ & Carcass & 0.91 & 0.14 \\
\hline 2 & 3 & ${ }^{60} \mathrm{Co}$ & Carcass & 0.96 & 0.17 \\
\hline 2 & 1 & ${ }^{60} \mathrm{Co}$ & Pelt & 0.96 & 0.15 \\
\hline 2 & 1 & ${ }^{152} \mathrm{Eu}$ & Carcass & 2.89 & 0.64 \\
\hline 2 & 2 & ${ }^{152} \mathrm{Eu}$ & Carcass & 2.13 & 0.54 \\
\hline 2 & 3 & ${ }^{152} \mathrm{Eu}$ & Carcass & 2.39 & 0.56 \\
\hline 2 & 1 & ${ }^{152} \mathrm{Eu}$ & Pelt & 2.94 & 0.71 \\
\hline 2 & 1 & ${ }^{40} \mathrm{~K}$ & Carcass & 43.87 & 5.22 \\
\hline 2 & 2 & ${ }^{40} \mathrm{~K}$ & Carcass & 46.35 & 5.35 \\
\hline 2 & 3 & ${ }^{40} \mathrm{~K}$ & Carcass & 45.39 & 5.32 \\
\hline 2 & 1 & ${ }^{40} \mathrm{~K}$ & Pelt & 40.22 & 4.86 \\
\hline 2 & 1 & ${ }^{208} \mathrm{Tl}$ & Carcass & 0.20 & 0.06 \\
\hline 2 & 2 & ${ }^{208} \mathrm{Tl}$ & Carcass & 0.15 & 0.05 \\
\hline 2 & 3 & ${ }^{208} \mathrm{Tl}$ & Carcass & 0.21 & 0.07 \\
\hline 2 & 1 & ${ }^{208} \mathrm{Tl}$ & Pelt & 0.16 & 0.06 \\
\hline 3 & 1 & total U & Carcass & 0.252 & 0.025 \\
\hline 3 & 2 & total U & Carcass & 0.174 & 0.017 \\
\hline 3 & 3 & total U & Carcass & 0.267 & 0.027 \\
\hline 3 & 1 & total U & Pelt & 0.979 & 0.196 \\
\hline 3 & 1 & ${ }^{241} \mathrm{Am}$ & Carcass & 0.009 & 0.030 \\
\hline 3 & 2 & ${ }^{2+1} \mathrm{Am}$ & Carcass & 0.003 & 0.030 \\
\hline 3 & 3 & ${ }^{241} \mathrm{Am}$ & Carcass & 0.007 & 0.030 \\
\hline 3 & 1 & ${ }^{241} \mathrm{Am}$ & Pelt & 0.014 & 0.030 \\
\hline 3 & 1 & ${ }^{238} \mathrm{Pu}$ & Carcass & 0.012 & 0.030 \\
\hline 3 & 2 & ${ }^{238} \mathrm{Pu}$ & Carcass & 0.006 & 0.030 \\
\hline 3 & 3 & ${ }^{238} \mathrm{Pu}$ & Carcass & 0.001 & 0.030 \\
\hline 3 & 1 & ${ }^{238} \mathrm{Pu}$ & Pelt & 0.003 & 0.030 \\
\hline 3 & 1 & ${ }^{239} \mathrm{Pu}$ & Carcass & 0.003 & 0.020 \\
\hline 3 & 2 & ${ }^{239} \mathrm{Pu}$ & Carcass & 0.001 & 0.020 \\
\hline 3 & 3 & ${ }^{239} \mathrm{Pu}$ & Carcass & 0.005 & 0.020 \\
\hline 3 & 1 & ${ }^{239} \mathrm{Pu}$ & Pelt & 0.037 & 0.020 \\
\hline 3 & 1 & ${ }^{90} \mathrm{Sr}$ & Carcass & 2.0 & 0.3 \\
\hline 3 & 2 & ${ }^{90} \mathrm{Sr}$ & Carcass & 1.8 & 0.3 \\
\hline 3 & 3 & ${ }^{90} \mathrm{Sr}$ & Carcass & 1.9 & 0.2 \\
\hline
\end{tabular}


Table 2 (cont.).

\begin{tabular}{|c|c|c|c|c|c|}
\hline SITE & $\begin{array}{l}\text { SAMPLE } \\
\text { NUMBER }\end{array}$ & RADIOISOTOPE & SAMPLE TYPE & $\begin{array}{c}\text { ANALYTICAL } \\
\text { RESULT }(\mu \mathrm{g} / \mathrm{g} \text { or } \\
\mathrm{pCi} / \mathrm{g})^{g}\end{array}$ & $\begin{array}{l}\text { ANALYTICAL } \\
\text { UNCERTAINTY }\end{array}$ \\
\hline 3 & 1 & ${ }^{90} \mathrm{Sr}$ & Pelt & 1.8 & 0.6 \\
\hline 3 & 1 & ${ }^{137} \mathrm{Cs}$ & Carcass & 0.12 & 0.05 \\
\hline 3 & 2 & ${ }^{137} \mathrm{Cs}$ & Carcass & 0.02 & 0.03 \\
\hline 3 & 3 & ${ }^{137} \mathrm{Cs}$ & Carcass & 0.06 & 0.09 \\
\hline 3 & 1 & ${ }^{137} \mathrm{Cs}$ & Pelt & 0.02 & 0.03 \\
\hline 3 & 1 & ${ }^{214} \mathrm{Bi}$ & Carcass & 0.30 & 0.14 \\
\hline 3 & 2 & ${ }^{214} \mathrm{Bi}$ & Carcass & 0.52 & 0.14 \\
\hline 3 & 3 & ${ }^{214} \mathrm{Bi}$ & Carcass & 0.39 & 0.18 \\
\hline 3 & 1 & ${ }^{214} \mathrm{Bi}$ & Pelt & 0.56 & 0.24 \\
\hline 3 & 1 & ${ }^{60} \mathrm{Co}$ & Carcass & 0.43 & 0.12 \\
\hline 3 & 2 & ${ }^{60} \mathrm{Co}$ & Carcass & 2.42 & 0.28 \\
\hline 3 & 3 & ${ }^{60} \mathrm{Co}$ & Carcass & 0.42 & 0.09 \\
\hline 3 & 1 & ${ }^{60} \mathrm{Co}$ & Pelt & 1.28 & 0.28 \\
\hline 3 & 1 & ${ }^{152} \mathrm{Eu}$ & Carcass & 0.17 & 0.26 \\
\hline 3 & 2 & ${ }^{152} \mathrm{Eu}$ & Carcass & 2.72 & 0.65 \\
\hline 3 & 3 & ${ }^{152} \mathrm{Eu}$ & Carcass & 0.10 & 0.15 \\
\hline 3 & 1 & ${ }^{152} \mathrm{Eu}$ & Pelt & 0.03 & 0.05 \\
\hline 3 & 1 & ${ }^{40} \mathrm{~K}$ & Carcass & 22.58 & 2.7 \\
\hline 3 & 2 & ${ }^{40} \mathrm{~K}$ & Carcass & 46.52 & 5.48 \\
\hline 3 & 3 & ${ }^{40} \mathrm{~K}$ & Carcass & 28.92 & 3.08 \\
\hline 3 & 1 & ${ }^{40} \mathrm{~K}$ & Pelt & 529.19 & 40.64 \\
\hline 3 & 1 & ${ }^{208} \mathrm{Tl}$ & Carcass & 0.17 & 0.06 \\
\hline 3 & 2 & ${ }^{208} \mathrm{Tl}$ & Carcass & 0.22 & 0.06 \\
\hline 3 & 3 & ${ }^{208} \mathrm{Tl}$ & Carcass & 0.16 & 0.06 \\
\hline 3 & 1 & ${ }^{208} \mathrm{Tl}$ & Pelt & 0.33 & 0.11 \\
\hline
\end{tabular}

${ }^{1}$ Total $U$ in measurements of $\mu \mathrm{g} / \mathrm{g}$; all other contaminant measurements are in $\mathrm{pCi} / \mathrm{g}$.

All carcass means were normally distributed (Table 3) with the exception of ${ }^{137} \mathrm{Cs}$ in Site 1 , total U in Site 2, and ${ }^{60} \mathrm{Co}$ and ${ }^{152} \mathrm{Eu}$ in Site 3. 
Table 3. Probability Values for Normality Test on Mean Concentration of Radionuclides by Carcass.

\begin{tabular}{|l|c|c|c|}
\hline CONTAMINANT & \multicolumn{3}{|c|}{ P Value $^{*}$} \\
\hline & SITE 1 & SITE 2 & SITE 3 \\
\hline${ }_{\text {total U }}$ & 0.5399 & 0.0413 & 0.2879 \\
\hline${ }^{241} \mathrm{Am}$ & 0.6368 & 0.3386 & 0.6368 \\
\hline${ }^{238} \mathrm{Pu}$ & 0.4099 & 0.2783 & 0.8995 \\
\hline${ }^{239} \mathrm{Pu}$ & 0.2500 & 0.7364 & 0.9916 \\
\hline${ }^{\text {}} \mathrm{Sr}$ & 0.6786 & 0.7016 & 0.9916 \\
\hline${ }^{137} \mathrm{Cs}$ & 0.0000 & 0.7803 & 0.7803 \\
\hline${ }^{214} \mathrm{Bi}$ & 0.8931 & 0.1939 & 0.8001 \\
\hline${ }^{60} \mathrm{Co}$ & 0.7562 & 0.7803 & 0.0083 \\
\hline${ }^{152} \mathrm{Eu}$ & 0.5367 & 0.6555 & 0.0447 \\
\hline${ }^{40} \mathrm{~K}$ & 0.4222 & 0.7523 & 0.4935 \\
\hline${ }^{208} \mathrm{Tl}$ & 0.4632 & 0.2982 & 0.8774 \\
\hline
\end{tabular}

* less than 0.05 indicates non-normal distribution

The mean concentration of each radionuclide found in carcasses and pelts by site is given in Tables 4 and 5, respectively, and shown in Figure 2. For most sites, the mean concentration of radionuclides in carcasses were lower than the concentrations found in pelts ${ }^{1}$ for total $\mathrm{U},{ }^{241} \mathrm{Am}$, ${ }^{238} \mathrm{Pu}$, and ${ }^{239} \mathrm{Pu}$. For the remaining radionuclides, concentrations in carcasses were usually nearly equal to or exceeded the mean concentrations in the pelts. An ANOVA test was used to determine if the mean radionuclide concentrations in carcasses were different between sites and Duncan's multiple range test used to show where the differences occurred. The results are discussed below.

\section{Total U}

There were no significant differences in total $U$ in carcasses between Sites 2 and 3. However, Site 1 had significantly higher (alpha $=0.05, \mathrm{P}=0.0095$ ) total $\mathrm{U}$ concentrations in carcasses than Sites 2 and 3 and was over two times higher than the control Site, 3.

\footnotetext{
${ }^{1}$ Only one composite pelt sample was analyzed per site due to low total ashed weight of combined samples.
} 
Table 4. Mean Radionuclide Concentrations for Small Mammal Carcass Samples.

\begin{tabular}{|c|c|c|c|c|c|c|c|c|c|}
\cline { 2 - 11 } \multicolumn{1}{c|}{} & \multicolumn{3}{c|}{ SITE 1 } & \multicolumn{3}{c|}{ SITE 2 } & \multicolumn{3}{c|}{ SITE 3 } \\
\hline RADIONUCLIDE & $\mathrm{N}$ & Mean & SE & $\mathrm{N}$ & Mean & SE & $\mathrm{N}$ & Mean & SE \\
\hline${ }^{214} \mathrm{Bi}$ & 3 & 0.57 & 0.089 & 3 & 0.467 & 0.029 & 3 & 0.403 & 0.064 \\
\hline${ }^{241} \mathrm{Am}$ & 3 & 0.01 & 0.001 & 3 & 0.051 & 0.025 & 3 & 0.006 & 0.002 \\
\hline${ }^{238} \mathrm{Pu}$ & 3 & 0.107 & 0.049 & 3 & 0.013 & 0.010 & 3 & 0.006 & 0.003 \\
\hline${ }^{137} \mathrm{Cs}$ & 3 & 0.04 & 0.000 & 3 & 0.033 & 0.015 & 3 & 0.067 & 0.029 \\
\hline${ }^{60} \mathrm{Co}$ & 3 & 1.023 & 0.052 & 3 & 0.937 & 1.090 & 3 & 1.09 & 0.665 \\
\hline${ }^{152} \mathrm{Eu}$ & 3 & 2.42 & 0.125 & 3 & 2.470 & 0.223 & 3 & 0.997 & 0.862 \\
\hline${ }^{208} \mathrm{Tl}$ & 3 & 0.243 & 0.012 & 3 & 0.187 & 0.019 & 3 & 0.217 & 0.026 \\
\hline${ }^{239} \mathrm{Pu}$ & 3 & 0.026 & 0.004 & 3 & 0.078 & 0.023 & 3 & 0.003 & 0.001 \\
\hline $\mathrm{U}$ & 3 & 0.487 & 0.054 & 3 & 0.344 & 0.027 & 3 & 0.231 & 0.029 \\
\hline${ }^{90} \mathrm{Sr}$ & 3 & 2.6 & 0.498 & 3 & 1.2 & 0.321 & 3 & 1.9 & 0.058 \\
\hline${ }^{40} \mathrm{~K}$ & 3 & 48.94 & 0.895 & 3 & 45.2 & 0.722 & 3 & 32.67 & 7.161 \\
\hline 1
\end{tabular}

1 Radionuclide concentrations for $U$ are measured $\mu \mathrm{g} / \mathrm{g}$; all other contaminants are measured in $\mathrm{pCi} / \mathrm{g}$.

Table 5. Radionuclide Concentrations ${ }^{1}$ for Small Mammal Pelt Samples.

\begin{tabular}{|c|c|c|c|c|c|c|}
\cline { 2 - 7 } \multicolumn{1}{c|}{} & \multicolumn{2}{c|}{ SITE 1 } & \multicolumn{2}{c|}{ SITE 2 } & \multicolumn{2}{c|}{ SITE 3 } \\
\hline RADIONUCLIDE & $\mathrm{N}$ & CONCENTRATION & $\mathrm{N}$ & CONCENTRATION & $\mathrm{N}$ & CONCENTRATION \\
\hline${ }^{214} \mathrm{Bi}$ & 1 & 0.42 & 1 & 0.44 & 1 & 0.56 \\
\hline${ }^{241} \mathrm{Am}$ & 1 & 0.052 & 1 & 1.14 & 1 & 0.014 \\
\hline${ }^{238} \mathrm{Pu}$ & 1 & 0.506 & 1 & 0.237 & 1 & 0.003 \\
\hline${ }^{137} \mathrm{Cs}$ & 1 & 0.02 & 1 & 0.03 & 1 & 0.02 \\
\hline${ }^{60} \mathrm{Co}$ & 1 & 0.99 & 1 & 0.96 & 1 & 1.28 \\
\hline${ }^{152} \mathrm{Eu}$ & 1 & 1.97 & 1 & 2.94 & 1 & 0.03 \\
\hline${ }^{208} \mathrm{Tl}$ & 1 & 0.26 & 1 & 0.16 & 1 & 0.33 \\
\hline${ }^{239} \mathrm{Pu}$ & 1 & 0.089 & 1 & 1.269 & 1 & 0.037 \\
\hline $\mathrm{U}$ & 1 & 1.931 & 1 & 1.362 & 1 & 0.979 \\
\hline${ }^{90} \mathrm{Sr}$ & 1 & 0.9 & 1 & 1.3 & 1 & 1.8 \\
\hline${ }^{40} \mathrm{~K}$ & 1 & 43.45 & 1 & 40.22 & 1 & 529.19 \\
\hline 1 Radionuclide concentrations for U are measured $\mu \mathrm{g} / \mathrm{g} ;$ all other contaminants are measured in $\mathrm{pCi} / \mathrm{g}$. \\
\hline
\end{tabular}

${ }^{241} \mathrm{Am},{ }^{238} \mathrm{Pu},{ }^{137} \mathrm{Cs},{ }^{214} \mathrm{Bi},{ }^{152} \mathrm{Eu},{ }^{60} \mathrm{Co},{ }^{208} \mathrm{Tl}$

There were no significant differences (alpha $=0.05)$ in concentrations of ${ }^{241} \mathrm{Am}(\mathrm{P}=0.1267),{ }^{238} \mathrm{Pu}$ $(\mathrm{P}=0.0846),{ }^{137} \mathrm{Cs}(\mathrm{P}=0.4607),{ }^{214} \mathrm{Bi}(\mathrm{P}=0.2697),{ }^{152} \mathrm{Eu}(\mathrm{P}=0.1539),{ }^{60} \mathrm{Co}(\mathrm{P}=0.9612)$, or ${ }^{208} \mathrm{Tl}$

$(P=0.2076)$ in rodent carcasses between sites. 
Figure 2. Radionuclide Concentrations in Small Mammals by Site, TA-54, Area G.
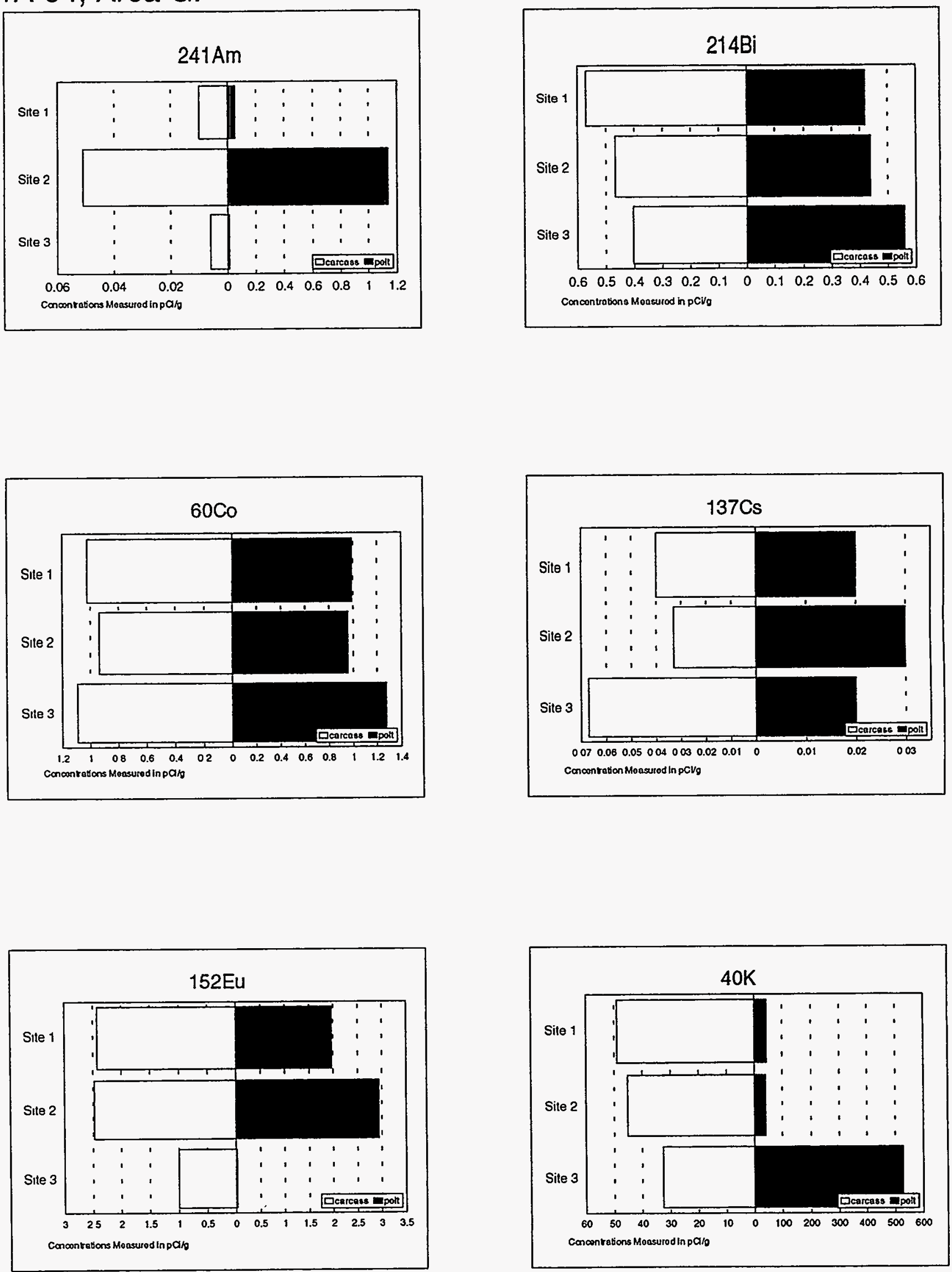
Figure 2 (cont.). Radionuclide Concentrations in Small Mammals by Site, TA-54, Area G.
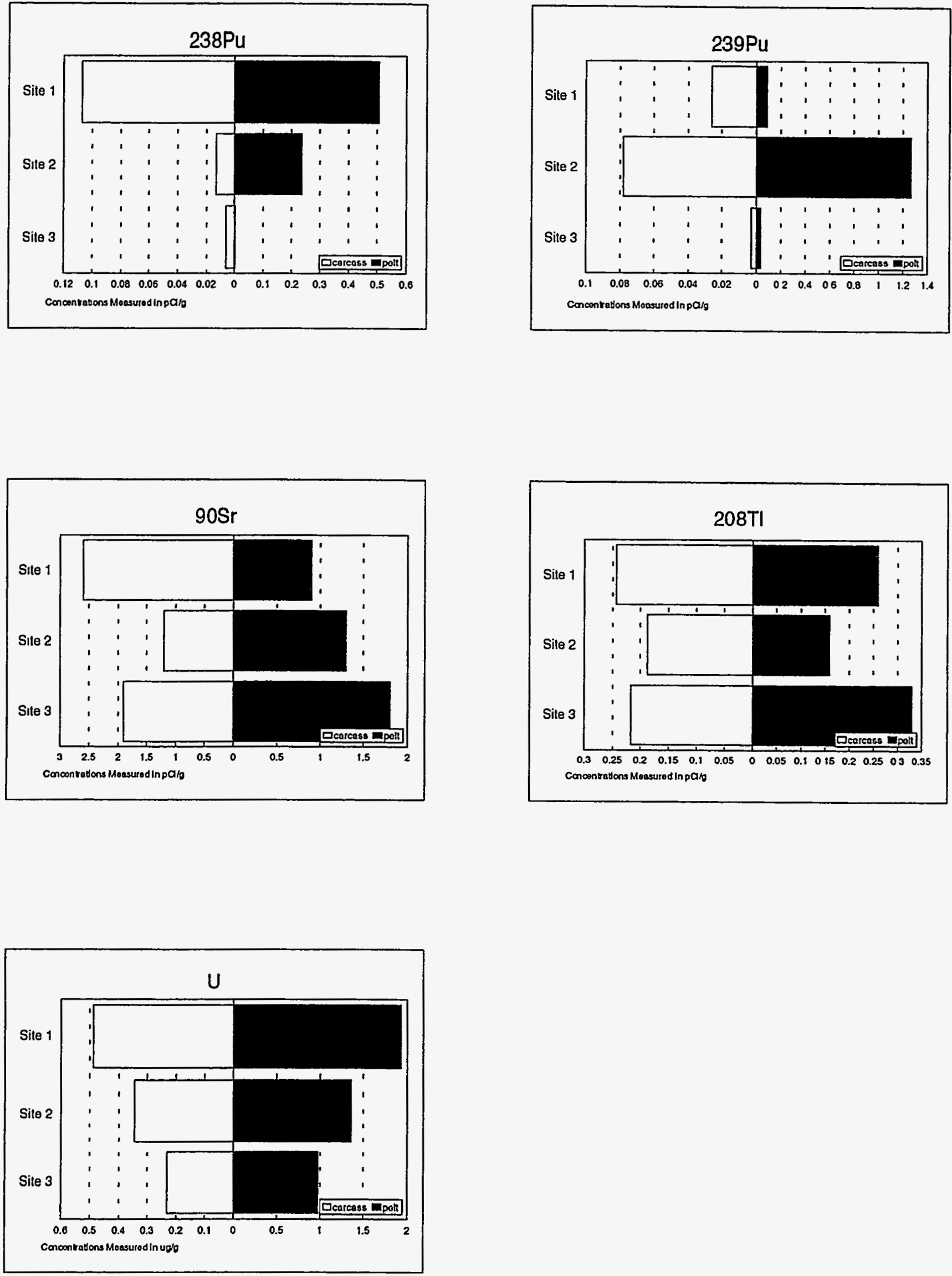
${ }^{239} \mathrm{Pu}$

No significant differences in concentrations of ${ }^{239} \mathrm{Pu}$ in carcasses occurred between Sites 1 and 3 but Site 2 had significantly higher (alpha=0.05, P=0.0195) ${ }^{239} \mathrm{Pu}$ concentrations in carcasses than either Site 1 or Site 3. Mean concentrations in carcasses at Site $2(0.078 \mathrm{pCi} / \mathrm{g})$ were 3 and 26 times higher than Sites 1 and 3, respectively.

${ }^{90} \mathrm{Sr}$

A significant difference in concentration of ${ }^{90} \mathrm{Sr}$ existed between Sites 1 and 2 (alpha=0.05, $\mathrm{P}=0.0681$ ) where the mean concentration of Site 1 was over two times that of Site 2.

$\underline{{ }^{40} \mathrm{~K}}$

Site 1 was significantly different from Site 3 for concentrations of ${ }^{40} \mathrm{~K}(\mathrm{P}=0.0742)$.

Analysis was conducted on overall mean concentrations of radionuclides to determine if differences existed between pelts and carcasses (Figure 3). The analysis was not conducted by site due to only one pelt sample per site being analyzed. For all sites combined, significant differences between pelt and carcass concentrations occurred for total $\mathrm{U},{ }^{241} \mathrm{Am},{ }^{238} \mathrm{Pu},{ }^{239} \mathrm{Pu}$, and ${ }^{40} \mathrm{~K}$, and in all cases, pelts had a higher concentration of radionuclides. There were no significant differences in radionuclide measurements in our studies between pelts and carcasses for ${ }^{90} \mathrm{Sr},{ }^{137} \mathrm{Cs},{ }^{214} \mathrm{Bi},{ }^{60} \mathrm{Co}$, ${ }^{152} \mathrm{Eu}$, and ${ }^{208} \mathrm{Tl}$.

\section{DISCUSSION}

This study was intended to establish baseline measurements of radionuclide concentrations in small mammals at Area G, TA-54, during the summer of 1994. The data can then be used to modify future studies at Area $G$ to better identify radionuclide transport and concentration loads in and around the site. 

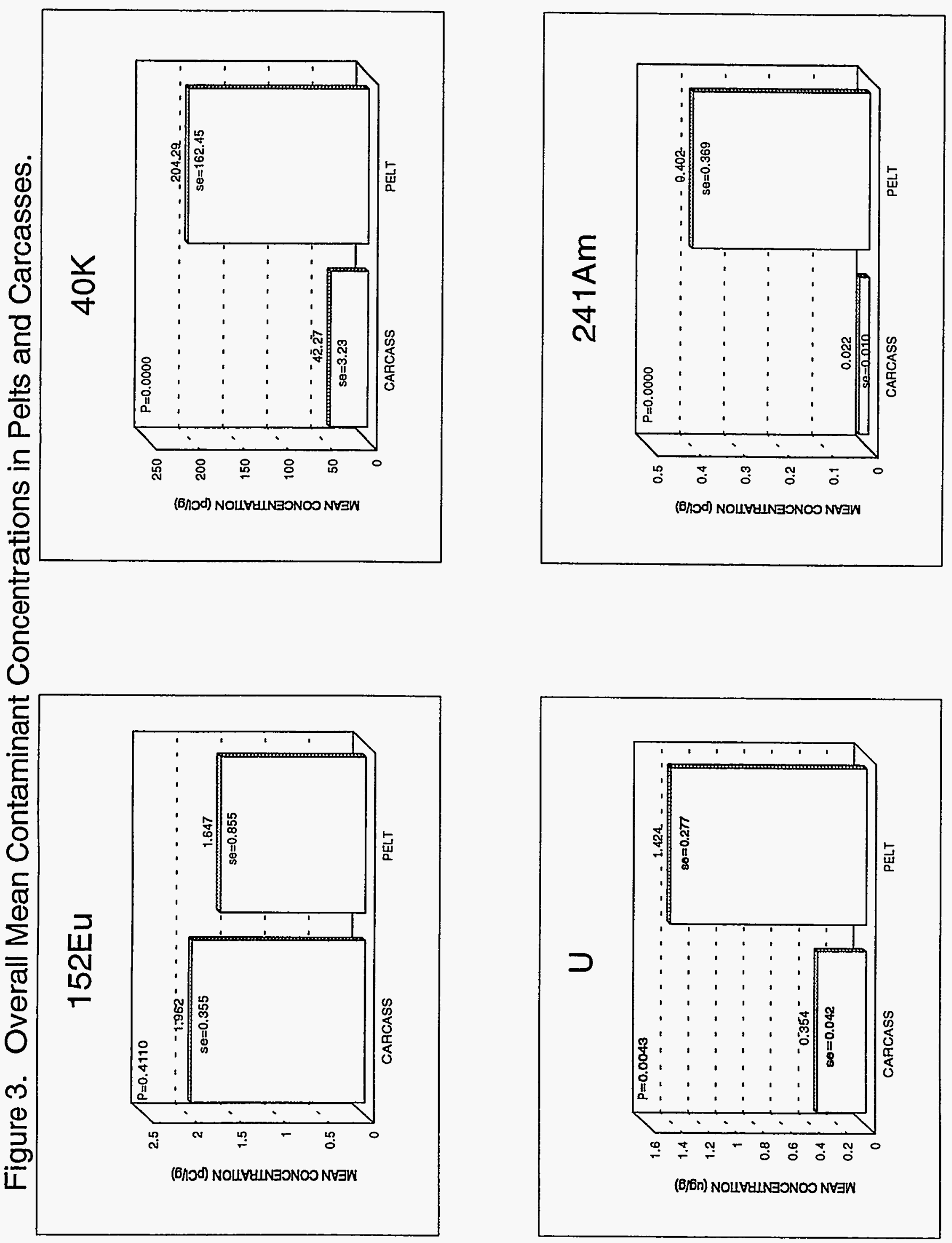

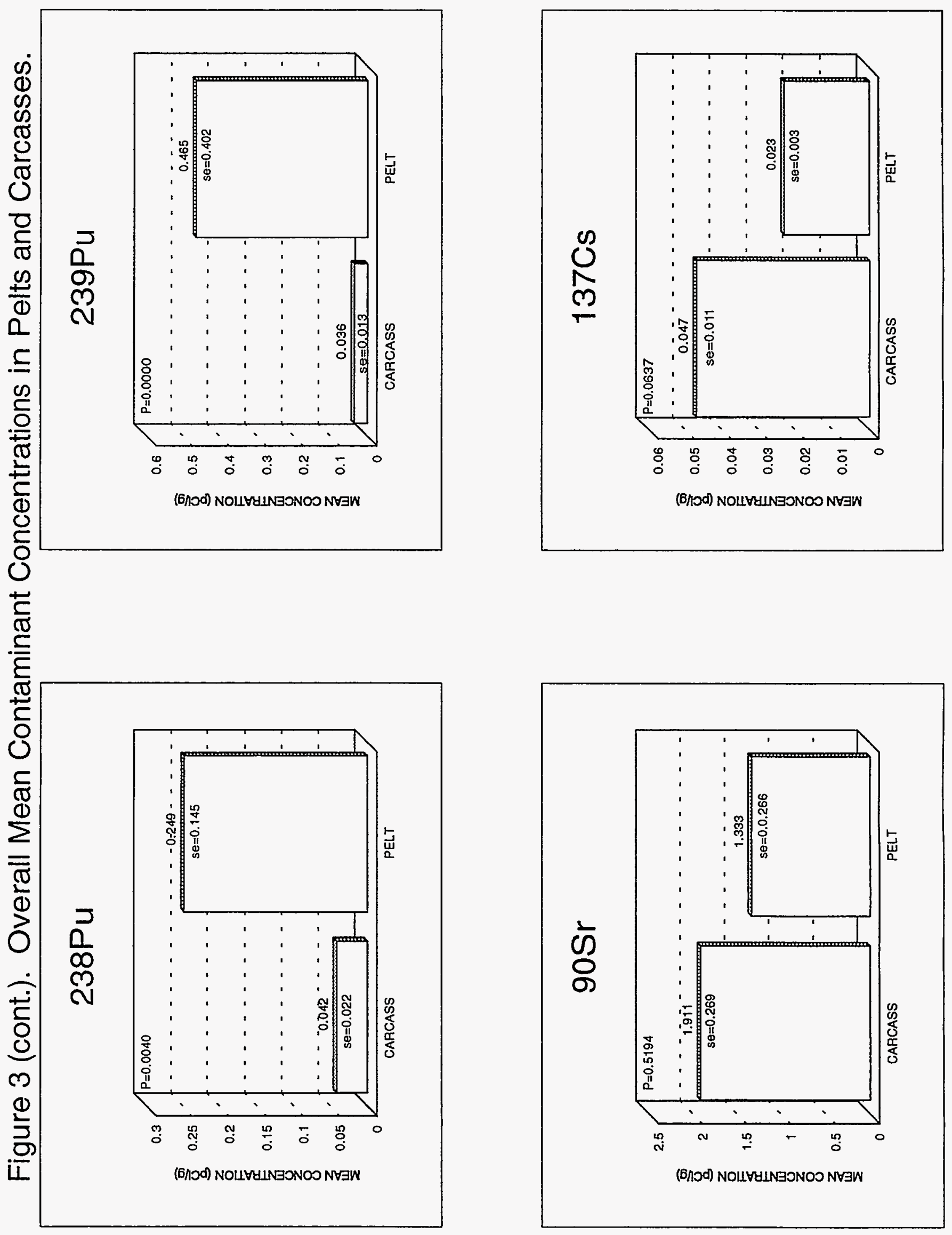

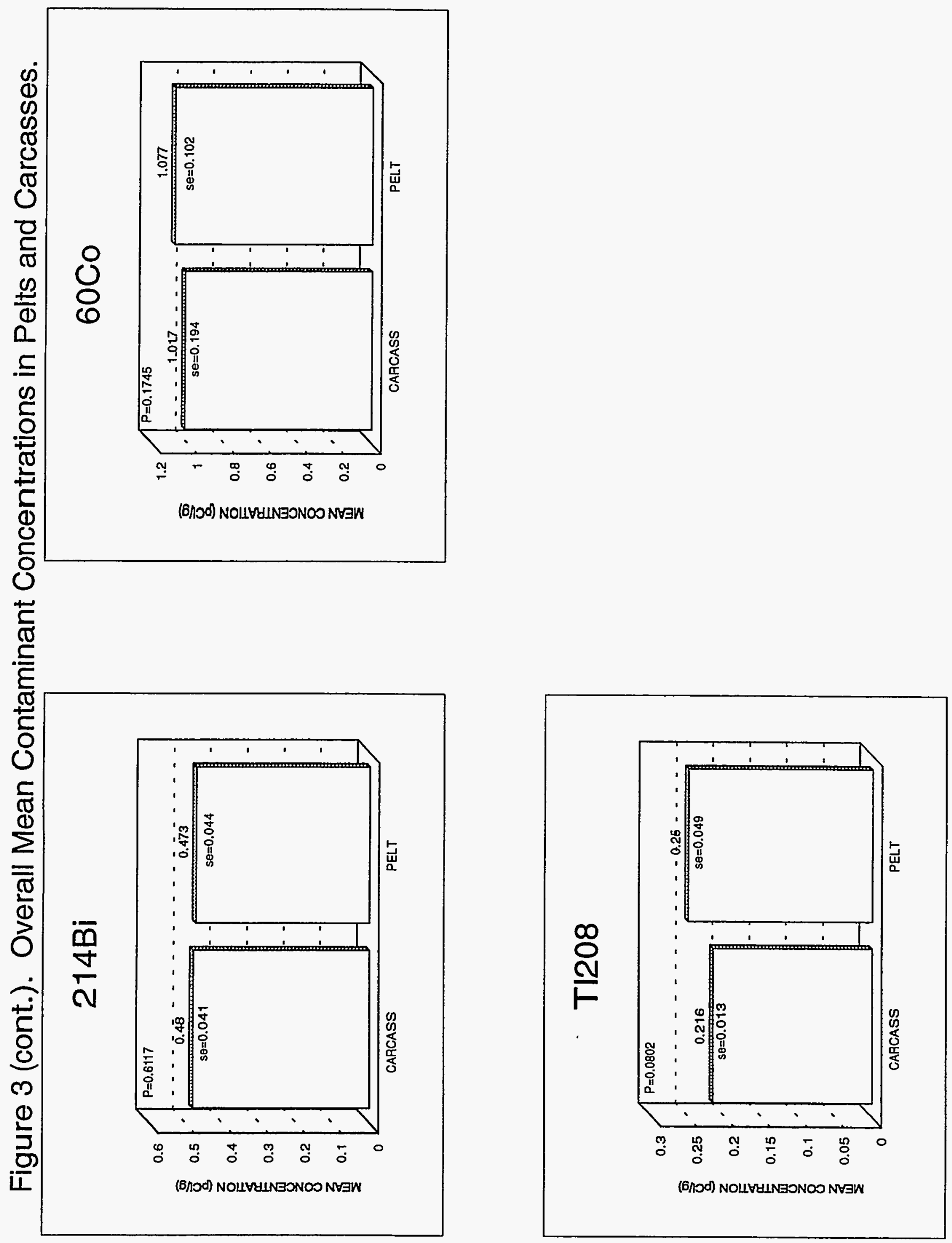
As shown in Table 1, higher densities of rodents were recorded for the two sites within Area G, both of which are located on predisturbed ground. Typically, at other predisturbed locations within Laboratory boundaries, small mammal densities have been higher than in undisturbed habitats. The low densities recorded for the control site is also typical of other studies conducted on mesa top habitats within Laboratory boundaries, especially within pinyon pine/juniper woodlands. The primary species collected at Sites 1 and 2 was deer mice. Deer mice are a more "opportunistic" species compared to other mice expected to occur in the vicinity of Area $\mathrm{G}$ and are therefore more likely to invade and populate the disturbed sites.

Our studies generally showed greater amounts of radionuclides in the pelts of animals compared to the carcass. In studies conducted at waste burial sites or contaminated sites outside of the Laboratory, similar results were found. Markham et.al. (1978) found higher concentrations of ${ }^{238} \mathrm{Pu},{ }^{239} \mathrm{Pu}$, and ${ }^{241} \mathrm{Am}$ in the pelts and gastrointestinal tracts compared to the carcass and lungs. Studies conducted at the Idaho National Engineering Laboratory on waste disposal sites also showed the highest concentration of ${ }^{238} \mathrm{Pu},{ }^{239+240} \mathrm{Pu},{ }^{241} \mathrm{Am},{ }^{90} \mathrm{Sr}$, and ${ }^{137} \mathrm{Cs}$ in pelt samples (Arthur et al., 1987).

Total U was shown to occur in significantly higher concentrations (in carcasses) at Site 1 compared to Sites 2 and 3. Also, Site 2 had higher concentrations of ${ }^{239} \mathrm{Pu}$ compared to Site 1 or 3 . Total U concentrations in vegetation collected at Site 1 indicate a range of 1.23 to $1.72 \mathrm{pCi} / \mathrm{g}$ ash (Fresquez et al. 1995) whereas concentrations in small mammal carcasses were less than $0.5 \mathrm{pCi} / \mathrm{g}$ ash. Vegetation collected at Site 1 had ${ }^{90} \mathrm{Sr}$ concentrations ranging from 2.0 to $3.3 \mathrm{pCi} / \mathrm{g}$ ash (Fresquez et al. 1995). The mean concentration of ${ }^{90} \mathrm{Sr}$ in small mammal carcasses at Site 1 was $2.6 \mathrm{pCi} / \mathrm{g}$ ash, well within the range of concentrations found in vegetation at that location. Additional studies and further monitoring of these sites will more accurately access if correlation's exist between radionuclide concentrations in vegetation and rodents. This information coupled with determining the mode (surface contact, inhalation/ingestion) of contamination to the animal 
can help to identify potential pathways of contaminants in a particular plant/animal community by examining if radionuclides are ingested, inhaled, or picked up via surface contact. Additional studies that are currently being conducted elsewhere at the Laboratory, coupled with past data collected at the Laboratory, will be used to more closely examine the relationship between food habits of small mammals and radionuclide uptake via vegetation. Knowledge of densities, food habits, and population dynamics will also help to estimate contaminant loads within the biota at the waste site as well as potential transport off the site. The information can also be used to gain a better understanding on the distribution of radionuclides within the biotic community of Area $G$ and its impact, if any, on biotic communities surrounding Area G. 


\section{ACKNOWLEDGMENTS}

We would like to thank field crew members Mary Salisbury, Eric Pacheco, and Laura Payne for their hard work and patience while collecting field data. We owe thanks to Mary Mullin for her help in calculating density estimates. We thank Louisa Lujan-Pacheco and Hector Hinojosa, CIC1, for editing the manuscript and Eric Vold, CST-14, for his assistance in site selection for trapping and for reviewing this manuscript. We would also like to thank Teralene Foxx, Acting Group Leader, ESH-20, for her support in attaining funds for this project. Finally, we would like to thank CST-14, The Solid Waste Management Program, for their support in funding this project. 


\section{REFERENCES}

Arthur, W.J., O.D. Markham, C.R. Groves, and B.L. Keller, "Radionuclide Export by Deer Mice at a Solid Radioactive Waste Disposal Area in Southeastern Idaho," Health Physics, Vol. 52, No. 1 (1987).

Biggs, J.R. and K. Bennett, "Application of "Guidelines for Reduction of Hantavirus Infection" to Field Studies of Rodent Populations in Northern New Mexico," Los Alamos National Laboratory report LA-UR-95-1471 (submitted to J. of Mammalogy) (1995).

Craig, T.H., D.K. Halfor, and O.D. Markham, "Radionuclide Concentrations of Nestling Raptors Near Nuclear Facilities," Wilson Bull. Vol. 91 (1979).

Eisler, R. "Radiation Hazards to Fish, Wildlife, and Invertebrates: A Synoptic Review. National Biological Service," Biolog. Report 26 (1994).

Eklund, B. (in collaboration with E. Vold, CST-14, Los Alamos National Laboratory) "Measurement of Emission Fluxes from Technical Area 54 Areas G and L 1995, Radian Corporation Austin, Tx.

Fresquez, P.R., J.R. Biggs, and K.D. Bennett, "Radionuclide Concentrations in Vegetation at Radioactive-Waste Disposal Area G During the 1994 Growing Season," Los Alamos National Laboratory report, LA-12954-MS (1995).

Hakonson, T.E., J.L. Martinez, and G.C. White, "Disturbance of a Low-level Waste Burial Site Cover by Pocket Gophers," Health Physics, Vol. 42, No. 6 (1982).

Markham, O.D., K.W. Puphal, and T.D. Filer, "Plutonium and Americium Contamination near a Transuranic Storage Area in Southeastern Idaho," J. Environ. Qual., Vol. 7, no. 3, (1978).

Mills, J.N., T.L. Yates, J.E. Childs, R.R. Parmenter, T.G. Ksiazek, P.E. Rollin, and C.J. Peters, "Guidelines for Working with Rodents Potentially Infected with Hantavirus, " (submitted to J. of Mammalogy).

O'Farrell, T.P. and R.O. Gilbert, "Transport of Radioactive Material by Jackrabbits on the Hanford Reservation," Health Physics, Vol. 29 (1985).

Salazar, J.G., "Produce and Fish Sampling Program of Los Alamos National Laboratory's Environmental Surveillance Group," Los Alamos National Laboratory report LA-10186-MS (1987)

Statistical Analysis System (SAS) Institute Inc. SAS/STAT User's Guide, Release 6.03 Edition. Cary, NC: SAS Institute Inc., (1988).

Seber, G.A., "The Estimation of Animal Abundance and Related Parameters (second ed.),". Charles Griffin and Co., London (1982) 
Winsor, T.F. and F. Ward Whicker, "Pocket Gophers and Redistribution of Plutonium in Soil,". Health Physics, Vol. 39 (1980). 


\section{APPENDIX A}

RAW DATA PRINTOUTS OF RADIONUCLIDE CONCENTRATIONS IN SMALL MAMMAL CARCASSES

AND PELTS, AREA G, 1994 
CUSTOMER SAMPLES:

\begin{tabular}{|c|c|c|c|c|c|c|}
\hline CUSTOHER & SAMPLE & ANALYTICAL & AMALYTICAL. & & COMPLETION & \\
\hline NUHBER & NUNBER & RESULT & UNCERTAINTY & UNITS & DATE & COMHENT \\
\hline $6222-1 C$ & 94.20468 & 1.7 & 0.2 & PCI/G & $1 / 11 / 95$ & \\
\hline $6222-2 c$ & 94.20469 & 0.6 & 0.2 & $\mathrm{PCI} / \mathrm{G}$ & $1 / 11 / 95$ & \\
\hline $6222-3 C$ & 94.20470 & 1.3 & 0.2 & $\mathrm{PCI} / \mathrm{G}$ & $1 / 11 / 95$ & \\
\hline $6222-p$ & 94.20471 & 1.3 & 0.8 & $\mathrm{PCl} / \mathrm{G}$ & $1 / 11 / 95$ & \\
\hline $6299-P$ & 94.20472 & 0.9 & 0.5 & $P C I / G$ & $1 / 11 / 95$ & \\
\hline $6219-1 C$ & 94.20473 & 1.7 & 0.2 & $\mathrm{PCI} / \mathrm{G}$ & $1 / 11 / 95$ & \\
\hline $6211-2 C$ & 94.20474 & 3.4 & 0.2 & $\mathrm{PCl} / \mathrm{G}$ & $1 / 11 / 95$ & \\
\hline $6219-3 c$ & $94.204 \pi 5$ & 2.8 & 0.3 & $\mathrm{PCl} / \mathrm{G}$ & $1 / 11 / 95$ & \\
\hline $6243-2 C$ & 94.20476 & 1.8 & 0.3 & PCI/G & $1 / 11 / 95$ & \\
\hline $6243-3 C$ & $94.204 \pi 7$ & 1.9 & 0.2 & $\mathrm{PCl} / \mathrm{G}$ & $-1 / 11 / 95$ & \\
\hline $6243-1 C$ & 94.20478 & 2. & 0.3 & $\mathrm{PCl} / \mathrm{G}$ & $1 / 11 / 95$ & \\
\hline $6243-P$ & 94.20479 & 1.8 & 0.6 & $\mathrm{PCl} / \mathrm{G}$ & $1 / 11 / 95$ & \\
\hline
\end{tabular}


REQUEST MUMBER: 18705 MATRIX: 82 ANALYST: RICHARO PETERS PROGRAM CODE: M36A OHNER: Philip R. Fresquez GROUP: ESH-20 MAIL-STOP: K490 PHONE: 7-0815

NOTEBOOK: $\quad$ PAGE:

CUSTOMER SAMPLES:

\begin{tabular}{|c|c|c|c|c|c|c|c|c|}
\hline \multirow{2}{*}{$\begin{array}{l}\text { CUSTOMER } \\
\text { NUM }\end{array}$} & \multirow{2}{*}{$\begin{array}{l}\text { SAKPLE } \\
\text { NUH }\end{array}$} & \multirow{2}{*}{ ANALYSIS } & \multirow{2}{*}{$\begin{array}{l}\text { ANALYTICAL } \\
\text { TECHNIOUE }\end{array}$} & \multirow{2}{*}{$\begin{array}{l}\text { ANALYTICAL } \\
\text { RESULT }\end{array}$} & \multirow{2}{*}{$\begin{array}{l}\text { ANALYTICAL } \\
\text { UNCERTAINTY }\end{array}$} & \multicolumn{3}{|c|}{ COMPLETION } \\
\hline & & & & & & UNITS & DATE & CONHENT \\
\hline $6222-1 C$ & 94.20468 & $A M-249$ & RAS & 0.099 & 0.03 & $\mathrm{PCI} / \mathrm{G}$ & $11 / 17 / 94$ & $77 \%$ \\
\hline $6222-1 C$ & 94.20468 & PU-238 & RAS & 0.0329 & 0.01 & PCI/G & $11 / 17 / 94$ & $31 \%$ \\
\hline $6222-1 C$ & 94.20468 & PU-239 & RAS & 0.1212 & 0.017 & PCI/G & $11 / 17 / 94$ & $31 \%$ \\
\hline $6222-2 C$ & 94.20469 & $A H-241$ & RAS & 0.034 & 0.03 & PCI/G & $11 / 17 / 94$ & $86 \%$ \\
\hline $6222-2 C$ & 94.20469 & PU-238 & RAS & 0.0008 & 0.0036 & $\mathrm{PCl} / \mathrm{G}$ & $11 / 17 / 94$ & $48 \%$ \\
\hline $6222-2 C$ & 94.20469 & PU-239 & RAS & 0.0719 & 0.0104 & PCI/G & $11 / 17 / 94$ & $48 \%$ \\
\hline $6222-3 c$ & 94.20470 & $A M-241$ & RAS & 0.019 & 0.03 & PCI/G & $11 / 17 / 94$ & $87 \%$ \\
\hline $6222-3 C$ & 94.20470 & $P U-238$ & RAS & 0.0056 & 0.0024 & $\mathrm{PCI} / \mathrm{G}$ & $11 / 17 / 94$ & $84 \%$ \\
\hline $6222-3 C$ & 94.20470 & PU-239 & RAS & 0.0416 & 0.0055 & $. P C I / G$ & $11 / 17 / 94$ & $84 \%$ \\
\hline $6222-P$ & 94.20471 & $A M-249$ & RAS & 1.14 & 0.071 & PCI/G & $11 / 17 / 94$ & $83 \%$ \\
\hline $6222-P$ & 94.20471 & PU-238 & RAS & 0.237 & 0.03 & PCI/G & $11 / 17 / 94$ & $74 \%$ \\
\hline $6222-P$ & 94.20471 & PU-239 & RAS & 1.269 & 0.079 & $\mathrm{PCl} / \mathrm{G}$ & $11 / 17 / 94$ & $74 \%$ \\
\hline $6211-P$ & 94.20472 & AH-241 & RAS & 0.052 & 0.03 & $\mathrm{PCI} / \mathrm{G}$ & $11 / 17 / 94$ & $54 \%$ \\
\hline $6211-P$ & 94.20472 & PU-238 & RAS & 0.506 & 0.035 & $\mathrm{PCI} / \mathrm{G}$ & $11 / 17 / 94$ & $83 \%$ \\
\hline $6211-P$ & 94.20472 & PU-239 & RAS & 0.089 & 0.02 & $\mathrm{PCl} / \mathrm{G}$ & $11 / 17 / 94$ & $83 \%$ \\
\hline $6211-1 C$ & 94.20473 & $A M-241$ & RAS & 0.01 & 0.03 & PCI/G & $11 / 17 / 94$ & $72 \%$ \\
\hline $6211-1 \mathrm{C}$ & 94.20473 & $P U-238$ & RAS & 0.137 & 0.031 & $\mathrm{PCI} / \mathrm{G}$ & $11 / 17 / 94$ & $8 \%$ \\
\hline $6211-1 C$ & 94.20473 & PU-239 & RAS & 0.034 & 0.02 & $\mathrm{PCI} / \mathrm{G}$ & $11 / 17 / 94$ & $8 \%$ \\
\hline $6211-2 C$ & 94.20474 & $A M-241$ & RAS & 0.009 & 0.03 & $P C I / G$ & $11 / 17 / 94$ & $83 \%$ \\
\hline $6211-2 c$ & 94.20474 & PU-238 & RAS & 0.1725 & 0.037 & PCI/G & $11 / 17 / 94$ & $12 \%$ \\
\hline $6211-2 C$ & 94.20474 & PU-239 & RAS & 0.0231 & 0.0147 & $\mathrm{PCI} / \mathrm{G}$ & $11 / 17 / 94$ & $12 \%$ \\
\hline $6211-3 C$ & 94.20475 & $A M-241$ & RAS & 0.012 & 0.03 & $P C I / G$ & $11 / 17 / 94$ & $92 \%$ \\
\hline $6211-3 c$ & 94.20475 & PU-238 & RAS & 0.012 & 0.03 & PCI/G & $11 / 17 / 94$ & $73 \%$ \\
\hline $6211-3 c$ & 94.20475 & PU-239 & RAS & 0.02 & 0.02 & PCI/G & $11 / 17 / 94$ & $73 \%$ \\
\hline $6243-2 C$ & 94.20476 & $A M-241$ & RAS & 0.003 & 0.03 & PCI/G & $11 / 17 / 94$ & $99 \%$ \\
\hline $6243-2 C$ & 94.20476 & PU-238 & RAS & 0.006 & 0.03 & $\mathrm{PCl} / \mathrm{G}$ & $11 / 17 / 94$ & $29 \%$ \\
\hline $6243-2 C$ & 94.20476 & PU-239 & RAS & 0.001 & 0.02 & $\mathrm{PCl} / \mathrm{G}$ & $11 / 17 / 94$ & $29 \%$ \\
\hline $6243-3 c$ & 94.20477 & $A M-241$ & RAS & 0.007 & 0.03 & $\mathrm{PCl} / \mathrm{G}$ & $11 / 17 / 94$ & $89 \%$ \\
\hline $6243-3 c$ & 94.20477 & $P U-238$ & RAS & 0.001 & 0.03 & PCI/G & $11 / 17 / 94$ & $79 \%$ \\
\hline $6243-3 c$ & 94.20477 & $P U-239$ & RAS & 0.005 & 0.02 & PCI/G & $11 / 17 / 94$ & $79 \%$ \\
\hline $6243-1 C$ & 94.20478 & $A M-241$ & RAS & 0.009 & 0.03 & $\mathrm{PCI} / \mathrm{G}$ & $11 / 17 / 94$ & $85 \%$ \\
\hline $6243-1 C$ & 94.20478 & PU-238 & RAS & 0.012 & 0.03 & $\mathrm{PCI} / \mathrm{G}$ & $11 / 17 / 94$ & $14 \%$ \\
\hline $6243-1 C$ & 94.20478 & PU-239 & RAS & 0.003 & 0.02 & $\mathrm{PCI} / \mathrm{G}$ & $11 / 17 / 94$ & $14 \%$ \\
\hline $6243-P$ & 94.20479 & AM-241 & RAS & 0.014 & 0.03 & $\mathrm{PCl} / \mathrm{G}$ & $11 / 17 / 94$ & $58 \%$ \\
\hline $6243-P$ & 94.20479 & $P U-238$ & RAS & 0.003 & 0.03 & $\mathrm{PCl} / \mathrm{G}$ & $11 / 17 / 94$ & $87 \%$ \\
\hline $6243-P$ & 94.20479 & PU-239 & RAS & 0.037 & 0.02 & $\mathrm{PCl} / \mathrm{G}$ & $11 / 17 / 94$ & $87 \%$ \\
\hline
\end{tabular}


$\star \star \star \star \star \star \star \star \star \star \star \star \quad$ EH -9 ANALYIICAL REPORT

Prepared by: AKS

REQUEST NUMBER: 18705
MATRIX:

on 16-Nov-1994

ANALYSIS: $U$

GROUP: ESH-20

MAIL-STOP: $K 490$

PHONE: $7-0815$

AHALYTICAL TECHNIOUE: KPA

ANALYTICAL PROCEDURE:

NOTESOOK:

PAGE:

CUSTOMER SAMPLES:

$\begin{array}{cccccc}\begin{array}{c}\text { CUSTOMER } \\ \text { NUMBER }\end{array} & \begin{array}{c}\text { SAMPLE } \\ \text { NUMBER }\end{array} & \begin{array}{c}\text { ANALYTICAL } \\ \text { RESULT }\end{array} & \begin{array}{c}\text { ANALYTICAL } \\ \text { UNCERTALNT }\end{array} & \text { UNITS } & \begin{array}{c}\text { COMPLETION } \\ \text { DATE }\end{array} \\ \text { C222-1C } & 94.20468 & 0.318 & 0.032 & \text { UG/G } & 11 / 16 / 94 \\ 6222-2 C & 94.20469 & 0.397 & 0.04 & \text { UG/G } & 11 / 16 / 94 \\ 6222-3 C & 94.20470 & 0.316 & 0.038 & \text { UG/G } & 11 / 16 / 94 \\ 6222-P & 94.20471 & 1.362 & 0.136 & \text { UG/G } & 11 / 16 / 94 \\ 6211-P & 94.20472 & 1.931 & 0.193 & \text { UG/G } & 11 / 16 / 94 \\ 6211-1 C & 94.20473 & 0.384 & 0.038 & \text { UG/G } & 11 / 16 / 94 \\ 6211-2 C & 94.20474 & 0.565 & 0.057 & \text { UG/G } & 11 / 16 / 94 \\ 6211-3 C & 94.20475 & 0.513 & 0.051 & \text { UG/G } & 11 / 16 / 94 \\ 6243-2 C & 94.20476 & 0.174 & 0.017 & \text { UG/G } & 11 / 16 / 94 \\ 6243-3 C & 94.20477 & 0.267 & 0.027 & \text { UG/G } & 11 / 16 / 94 \\ 6243-1 C & 94.20478 & 0.252 & 0.025 & \text { UG/G } & 11 / 16 / 94 \\ 6243-P & 94.20479 & 0.979 & 0.196 & \text { UG/G } & -11 / 16 / 94\end{array}$


OWNER: Philip R. Fresquez GROUP: ESH-20 MAIL-STOP: M887 PHONE: 7-0815

HOTEBOOK:

PAGE:

CUSTOMER SAMPLES:

\begin{tabular}{|c|c|c|c|c|c|c|c|c|}
\hline \multirow{2}{*}{$\begin{array}{l}\text { CUSTOMER } \\
\text { MUM }\end{array}$} & \multirow{2}{*}{$\begin{array}{c}\text { SAMPLE } \\
\text { HUH }\end{array}$} & \multirow[b]{2}{*}{ AHALYSIS } & \multirow{2}{*}{$\begin{array}{l}\text { ANALYTICAL } \\
\text { TECHKIQUE }\end{array}$} & \multirow{2}{*}{$\begin{array}{c}\text { AKALYTICAL } \\
\text { RESULT }\end{array}$} & \multirow{2}{*}{$\begin{array}{l}\text { ANALYTICAL } \\
\text { UNCERTAIHTY }\end{array}$} & \multicolumn{3}{|c|}{ COMPLETIOH } \\
\hline & & & & & & UHITS & DATE & CONMENT \\
\hline $6222-1 C$ & 94.20468 & $B A-140$ & G & 9.82 & 14.73 & $P C l / G$ & $4 / 12 / 95$ & \\
\hline $6222-1 C$ & 94.20468 & $B 1-212$ & G & 0.17 & 0.26 & $\mathrm{PCI} / \mathrm{G}$ & $4 / 12 / 95$ & \\
\hline $6222-1 C$ & 94.20468 & $B 1-214$ & G & 0.49 & 0.12 & PCI/G & $4 / 12 / 95$ & \\
\hline $6222-1 C$ & 94.20468 & $C E-144$ & G & 0.46 & 0.69 & $\mathrm{PCI} / \mathrm{G}$ & $4 / 12 / 95$ & \\
\hline $6222-1 c$ & 94.20468 & $c 0-57$ & G & 0.07 & 0.03 & PCI/G & $4 / 12 / 95$ & \\
\hline $6222-1 C$ & 94.20468 & $c 0-60$ & G & 0.94 & 0.12 & PCI/G & $4 / 12 / 95$ & \\
\hline $6222-1 C$ & 94.20468 & CS- 134 & $\mathbf{G}$ & 0.04 & 0.06 & $\mathrm{PCI} / \mathrm{G}$ & $4 / 12 / 95$ & \\
\hline $6222-16$ & 94.20468 & CS-137 & G & 0.01 & 0.02 & $P C I / G$ & $4 / 12 / 95$ & \\
\hline $6222-1 C$ & 94.20468 & EU-152 & $\mathbf{G}$ & 2.89 & 0.64 & PCI/G & $4 / 12 / 95$ & \\
\hline $6222-1 C$ & 94.20468 & $K-40$ & G & 43.87 & 5.22 & $P C I / G$ & $4 / 12 / 95$ & \\
\hline $6222-1 C$ & 94.20468 & $L A-140$ & G & 0.0 & & PCI/G & $4 / 12 / 95$ & \\
\hline $6222-1 C$ & 94.20468 & MH-54 & G & 0.11 & 0.06 & $\mathrm{PCI} / \mathrm{G}$ & $4 / 12 / 95$ & \\
\hline $6222-1 C$ & 94.20468 & $\mathrm{MA-22}$ & G & 0.22 & 0.08 & $P C I / G$ & $4 / 12 / 95$ & \\
\hline $6222-1 C$ & 94.20468 & $N P-237$ & G & 0.09 & 0.14 & $P C I / G$ & $4 / 12 / 95$ & \\
\hline $6222-1 C$ & 94.20468 & $P A-231$ & G & 1.61 & 2.42 & $\mathrm{PCI} / \mathrm{G}$ & $4 / 12 / 95$ & \\
\hline $6222-1 C$ & 94.20468 & $P A-233$ & G & 0.82 & 1.23 & PCI/G & $4 / 12 / 95$ & \\
\hline $6222-1 C$ & 94.20468 & PB-210 & G & 0.0 & 2.7 & $P C I / G$ & $4 / 12 / 95$ & \\
\hline $6222-1 C$ & 94.20468 & PB-212 & $\mathbf{G}$ & 0.17 & 0.07 & $\mathrm{PCl} / \mathrm{G}$ & $4 / 12 / 95$ & \\
\hline $6222-1 C$ & 94.20468 & PB-214 & G & 0.24 & 0.08 & $P C I / G$ & $4 / 12 / 95$ & \\
\hline $6222-1 c$ & 94.20468 & RA-223 & G & 42.86 & 64.29 & $\mathrm{PCI} / \mathrm{G}$ & $.4 / 12 / 95$ & \\
\hline $6222-1 C$ & 94.20468 & $R A-224$ & G & 0.11 & 0.17 & PCI/G & $4 / 12 / 95$ & \\
\hline $6222-1 C$ & 94.20468 & $R A-226$ & G & 0.79 & 1.19 & $P C I / G$ & $4 / 12 / 95$ & \\
\hline $6222-1 C$ & 94.20468 & $R H-219$ & G & 0.79 & 0.3 & PCI/G & $4 / 12 / 95$ & \\
\hline $6222-1 C$ & 94.20468 & RU-106 & G & 0.08 & 0.12 & $P C I / G$ & $4 / 12 / 95$ & \\
\hline $6222-1 C$ & 94.20468 & SE- 75 & $\mathbf{G}$ & 0.08 & 0.12 & PCI/G & $4 / 12 / 95$ & \\
\hline $6222-1 C$ & 94.20468 & $T L-208$ & G & 0.2 & 0.06 & $P C I / G$ & 4/12/95 & \\
\hline $6222-10$ & 94.20468 & $2 H-65$ & G & 0.75 & 1.13 & PCI/G & $4 / 12 / 95$ & \\
\hline $6222-2 c$ & 94.20469 & $B A-140$ & $\mathbf{G}$ & 42.55 & 63.83 & $\mathrm{PCI} / \mathrm{G}$ & $4 / 12 / 95$ & \\
\hline $6222-2 C$ & 94.20469 & $81-212$ & $\mathbf{G}$ & 0.18 & 0.27 & $P C I / G$ & $4 / 12 / 95$ & \\
\hline $6222-2 C$ & 94.20469 & BI -214 & $\mathbf{G}$ & 0.41 & 0.11 & PCl/G & $4 / 12 / 95$ & \\
\hline $6222-2 C$ & 94.20469 & CE- 144 & G & 0.41 & 0.62 & PCI/G & $4 / 12 / 95$ & \\
\hline $6222-2 C$ & 94.20469 & $c 0-57$ & $\mathbf{G}$ & 0.05 & 0.08 & $\mathrm{PCl} / \mathrm{G}$ & $4 / 12 / 95$ & \\
\hline $6222-2 C$ & 94.20469 & $10-60$ & G & 0.91 & 0.14 & $\mathrm{PCl} / \mathrm{G}$ & $4 / 12 / 95$ & \\
\hline $6222-2 c$ & 94.20469 & CS-134 & $G$ & 0.01 & 0.02 & $P C I / G$ & $4 / 12 / 95$ & \\
\hline $6222-2 C$ & 94.20469 & CS-137 & G & 0.03 & 0.05 & $\mathrm{PCI} / \mathrm{G}$ & $4 / 12 / 95$ & \\
\hline $6222-2 C$ & 94.20469 & EU-152 & G & 2.13 & 0.54 & $\mathrm{PCI} / \mathrm{G}$ & $4 / 12 / 95$ & \\
\hline $6222-2 C$ & 94.20469 & $x-40$ & G & 46.35 & 5.35 & PCI/G & $4 / 12 / 95$ & \\
\hline
\end{tabular}




\begin{tabular}{|c|c|c|c|c|c|c|c|}
\hline $6222-2 c$ & 94.20469 & $L A=140$ & 6 & 0.0 & & $\mathrm{PCI} / \mathrm{G}$ & $4 / 12 / 95$ \\
\hline $6222-2 C$ & 94.20469 & $M N-54$ & G & 0.08 & 0.12 & PCI/G & $4 / 12 / 95$ \\
\hline $6222-2 c$ & 94.20469 & HA-22 & G & 0.1 & 0.15 & $\mathrm{PCl} / \mathrm{G}$ & $4 / 12 / 95$ \\
\hline $6222-2 C$ & 94.20469 & NP-237 & G & 0.3 & 0.45 & $\mathrm{PCl} / \mathrm{G}$ & $4 / 12 / 95$ \\
\hline $6222-2 c$ & 94.20469 & $P A-231$ & G & 1.42 & 2.13 & PCI/G & $4 / 12 / 95$ \\
\hline $6222-2 c$ & 94.20469 & $P A-233$ & $G$ & 0.14 & 0.21 & $\mathrm{PCl} / \mathrm{G}$ & $4 / 12 / 95$ \\
\hline $6222-2 C$ & 94.20469 & PB-210 & $G$ & 0.0 & 2.7 & $\mathrm{PCl} / \mathrm{G}$ & $4 / 12 / 95$ \\
\hline $6222-2 c$ & 94.20469 & $P B=212$ & $G$ & 0.24 & 0.07 & $\mathrm{PCl} / \mathrm{G}$ & $4 / 12 / 95$ \\
\hline $6222 \cdot 2 C$ & 94.20469 & PB-214 & G & 0.31 & 0.08 & PCl/G & $4 / 12 / 95$ \\
\hline $6222-2 C$ & 94.20469 & $R A-223$ & G & 0.0 & & $\mathrm{PCl} / \mathrm{G}$ & $4 / 12 / 95$ \\
\hline $6222-2 C$ & 94.20469 & $R A-224$ & $G$ & 0.37 & 0.56 & PCI/G & $4 / 12 / 95$ \\
\hline $6222-2 c$ & 94.20469 & $R A-226$ & G & 0.06 & 0.09 & PCI/G & $4 / 12 / 95$ \\
\hline $6222-2 C$ & 94.20469 & RH-219 & G & 0.05 & 0.08 & $\mathrm{PCl} / \mathrm{G}$ & $4 / 12 / 95$ \\
\hline $6222-2 c$ & 94.20469 & $R U-106$ & G & 0.52 & 0.78 & $\mathrm{PCl} / \mathrm{G}$ & $4 / 12 / 95$ \\
\hline $6222-2 C$ & 94.20469 & $S E-73$ & G & 0.09 & 0.14 & PCI/G & $4 / 12 / 95$ \\
\hline $6222-2 C$ & 94.20469 & $T L-208$ & G & 0.15 & 0.05 & $P C l / G$ & $4 / 12 / 95$ \\
\hline $6222-2 C$ & 94.20469 & $2 \mathrm{H}-65$ & G & 0.8 & 0.22 & PCI/G & $4 / 12 / 95$ \\
\hline $6222-3 c$ & 94.20470. & $B A-940$ & G & 34.02 & 51.03 & $\mathrm{PCl} / \mathrm{G}$ & $4 / 12 / 95$ \\
\hline $6222-3 c$ & 94.20470 & BI -212 & 6 & 0.3 & 0.45 & PCI/G & $4 / 12 / 95$ \\
\hline $6222-3 c$ & 94.20470 & BI-214 & G & 0.5 & 0.14 & $P C I / G$ & $4 / 12 / 95$ \\
\hline $6222-3 c$ & 94.20470 & CE- 144 & G & 0.23 & & $P C I / G$ & $4 / 12 / 95$ \\
\hline $6222-3 c$ & 94.20470 & CO-57 & G & 0.06 & 0.03 & $\mathrm{PCl} / \mathrm{G}$ & $4 / 12 / 95$ \\
\hline $6222-3 c$ & 94.20470 & $\mathrm{CO}-60$ & G & 0.96 & 0.17 & $\mathrm{PCl} / \mathrm{G}$ & $4 / 12 / 95$ \\
\hline $6222-3 c$ & 94.20470 & CS- 134 & $\mathbf{G}$ & 0.05 & 0.08 & PCI/G & $4 / 12 / 95$ \\
\hline $6222-3 c$ & 94.20470 & $C S-137$ & $\mathbf{G}$ & 0.06 & 0.09 & PCI/G & $4 / 12 / 95$ \\
\hline $6222 \cdot 3 c$ & 94.20470 & EU-152 & $G$ & 2.39 & 0.56 & $\mathrm{PCI} / \mathrm{G}$ & $4 / 12 / 95$ \\
\hline $6222-3 c$ & 94.20470 & $K-40$ & $\mathbf{G}$ & 45.39 & 5.32 & $\mathrm{PCI} / \mathrm{G}$ & $4 / 12 / 95$ \\
\hline $6222-3 c$ & 94.20470 & $1 A-140$ & 6 & 0.0 & & PCI/G & $4 / 12 / 95$ \\
\hline $6222 \cdot 3 C$ & 94.20470 & MH-54 & $G$ & 0.15 & 0.23 & PCI/G & $4 / 12 / 95$ \\
\hline $6222-3 c$ & 94.20470 & $N A-22$ & G & 0.15 & 0.07 & $\mathrm{PCI} / \mathrm{G}$ & $4 / 12 / 95$ \\
\hline $6222-3 C$ & 94.20470 & NP- 237 & G & 0.03 & 0.05 & $\mathrm{PCl} / \mathrm{G}$ & $4 / 12 / 95$ \\
\hline $6222-3 C$ & 94.20470 & $P A-231$ & $\mathbf{G}$ & 1.52 & 2.28 & PCI/G & $4 / 12 / 95$ \\
\hline $6222-3 c$ & 94.20470 & $P A-233$ & G & 0.11 & 0.17 & $\mathrm{PCl} / \mathrm{G}$ & $4 / 12 / 95$ \\
\hline $6222-3 c$ & 94.20470 & PB-210 & G & 0.0 & 2.7 & PCI/G & $4 / 12 / 95$ \\
\hline $6222-3 c$ & 94.20470 & PB-212 & $\mathbf{G}$ & 0.1 & 0.15 & $P C I / G$ & $4 / 12 / 95$ \\
\hline $6222-3 C$ & 94.20470 & PB-214 & G & 0.18 & 0.05 & $\mathrm{PCl} / \mathrm{G}$ & $4 / 12 / 95$ \\
\hline $6222 \cdot 3 c$ & 94.20470 & $R A-223$ & G & 0.0 & & $\mathrm{PCl} / \mathrm{G}$ & $4 / 12 / 95$ \\
\hline $6222 \cdot 3 c$ & 94.20470 & $R A-224$ & $G$ & 0.56 & 0.84 & PCI/G & $4 / 12 / 95$ \\
\hline $6222-3 c$ & 94.20470 & $R A-226$ & G & 0.41 & 0.62 & $P C l / G$ & $4 / 12 / 95$ \\
\hline $6222-3 c$ & 94.20470 & RN-219 & 6 & 0.68 & 0.23 & PCI/G & $4 / 12 / 95$ \\
\hline $6222-3 c$ & 94.20470 & RU-106 & G & 0.85 & 1.28 & $\mathrm{PCl} / \mathrm{G}$ & $4 / 12 / 95$ \\
\hline $6222-3 c$ & 94.20470 & SE- 75 & G & 0.09 & 0.14 & PCI/G & $4 / 12 / 95$ \\
\hline $6222 \cdot 3 c$ & 94.20470 & $T L-208$ & G & 0.21 & 0.07 & $\mathrm{PCI} / \mathrm{G}$ & 4/12/95 \\
\hline $6222-3 c$ & 94.20470 & $2 N-65$ & G & 0.62 & 0.21 & $\mathrm{PCl} / \mathrm{G}$ & $4 / 12 / 95$ \\
\hline $6222-P$ & 94.20471 & $B A-140$ & $G$ & 1.09 & 1.64 & PCI/G & $4 / 12 / 95$ \\
\hline $6222-P$ & 94.20471 & BI-212 & G & 1.25 & 0.61 & PCI/G & $4 / 12 / 95$ \\
\hline $6222-P$ & 94.20471 & BI -214 & G & 0.44 & 0.13 & $\mathrm{PCI} / \mathrm{G}$ & $4 / 12 / 95$ \\
\hline $6222-P$ & 94.20471 & CE- 144 & G & 0.21 & 0.32 & $\mathrm{PCl} / \mathrm{G}$ & $4 / 12 / 95$ \\
\hline $6222-P$ & 94.20471 & $c 0.57$ & G & 0.09 & 0.03 & $\mathrm{PCl} / \mathrm{G}$ & $4 / 12 / 95$ \\
\hline $6222 \cdot P$ & 94.20471 & $c 0-60$ & $G$ & 0.96 & 0.15 & $\mathrm{PCl} / \mathrm{G}$ & $4 / 12 / 95$ \\
\hline $6222-P$ & 94.20471 & CS-134 & G & 0.08 & 0.03 & $\mathrm{PCl} / \mathrm{G}$ & $4 / 12 / 95$ \\
\hline $6222-P$ & 94.20471 & cs-137 & G & 0.03 & 0.05 & $\mathrm{PCl} / \mathrm{G}$ & $4 / 12 / 95$ \\
\hline $6222-P$ & 94.20471 & EU- 152 & 6 & 2.94 & 0.71 & $\mathrm{PCl} / \mathrm{G}$ & $4 / 12 / 95$ \\
\hline $6222-P$ & 94.20471 & $k-40$ & $\mathbf{G}$ & 40.22 & 4.86 & $\mathrm{PCl} / \mathrm{G}$ & $4 / 12 / 95$ \\
\hline $6222-P$ & 94.20471 & $L A \cdot 140$ & $\mathbf{G}$ & 0.0 & & $\mathrm{PCl} / \mathrm{G}$ & $4 / 12 / 95$ \\
\hline $6222-p$ & 94.20479 & $M N \cdot 54$ & $G$ & 0.07 & 0.11 & $\mathrm{PCl} / \mathrm{G}$ & $4 / 12 / 95$ \\
\hline $6222-P$ & 94.20471 & HA-22 & $\mathbf{G}$ & 0.19 & 0.29 & $P C I / G$ & $4 / 92 / 95$ \\
\hline $6222-p$ & 94.20471 & NP- 237 & $G$ & 0.41 & 0.62 & $\mathrm{PCl} / \mathrm{G}$ & $4 / 12 / 95$ \\
\hline $6222-P$ & 94.20479 & $P A-231$ & $G$ & 0.35 & 0.53 & $\mathrm{PCl} / \mathrm{G}$ & $4 / 12 / 95$ \\
\hline $6222-p$ & 94.20471 & PA-233 & $G$ & 0.75 & 912 & זיונס & De. \\
\hline
\end{tabular}




\begin{tabular}{|c|c|c|c|c|c|c|}
\hline $6222-P$ & 94.20471 PB-210 & G & 0.0 & 2.7 & $\mathrm{PCl} / \mathrm{G}$ & $4 / 12 / 95$ \\
\hline $6222 \cdot p$ & 94.20471 PB-212 & $\mathbf{G}$ & 0.11 & 0.06 & $\mathrm{PCl} / \mathrm{G}$ & $4 / 12 / 95$ \\
\hline $6222-p$ & 94.20471 PB-214 & $\mathbf{G}$ & 0.11 & 0.05 & $\mathrm{PCI} / \mathrm{G}$ & $4 / 12 / 95$ \\
\hline $6222-p$ & 94.20471 RA-223 & $G$ & 3.71 & 5.57 & $\mathrm{PCl} / \mathrm{G}$ & $4 / 12 / 95$ \\
\hline $6222-P$ & 94.20471 RA-224 & $\mathbf{G}$ & 0.53 & 0.8 & PCI/G & $4 / 12 / 95$ \\
\hline $6222-P$ & 94.20471 RA-226 & G & 0.01 & 0.02 & $\mathrm{PCl} / \mathrm{G}$ & $4 / 12 / 95$ \\
\hline 6222-P & 94.20471 RH-219 & $\mathbf{G}$ & 1.09 & 1.64 & PCl/G & $4 / 12 / 95$ \\
\hline $6222-P$ & 94.20471 RU- 106 & G & 0.34 & 0.51 & $\mathrm{PCl} / \mathrm{G}$ & $4 / 12 / 95$ \\
\hline $6222-P$ & $94.20471 \mathrm{SE}-75$ & G & 0.07 & 0.11 & $\mathrm{PCl} / \mathrm{G}$ & $4 / 12 / 95$ \\
\hline $6222-P$ & 94.20471 TL-208 & $\mathbf{G}$ & 0.16 & 0.06 & $\mathrm{PCl} / \mathrm{G}$ & $4 / 12 / 95$ \\
\hline 6222-P & $94.204712 \mathrm{H}-65$ & $\mathbf{G}$ & 0.17 & 0.26 & PCI/G & $4 / 12 / 95$ \\
\hline $6211 \cdot p$ & $94.20472 \mathrm{BA} \cdot 140$ & G & 9.94 & 14.91 & $\mathrm{PCl} / \mathrm{G}$ & $4 / 12 / 95$ \\
\hline $6211-p$ & 94.20472 BI -212 & G & 0.63 & 0.95 & $\mathrm{PCl} / \mathrm{G}$ & $4 / 12 / 95$ \\
\hline $6211-p$ & 94.20472 BI-214 & $\mathbf{G}$ & 0.42 & 0.14 & $\mathrm{PCl} / \mathrm{G}$ & $4 / 12 / 95$ \\
\hline $6211-p$ & 94.20472 CE- 144 & G & 0.33 & 0.5 & $\mathrm{PCl} / \mathrm{G}$ & $4 / 12 / 95$ \\
\hline $6211-p$ & $94.20472 \mathrm{co.57}$ & G & 0.01 & 0.03 & PCI/G & $4 / 12 / 95$ \\
\hline $6211-p$ & $94.20472 \mathrm{co-60}$ & G & 0.99 & 0.15 & PCI/G & $4 / 12 / 95$ \\
\hline $6211-p$ & 94.20472 CS -134 & G & 0.05 & 0.08 & PCI/G & $4 / 12 / 95$ \\
\hline $6211-p$ & 94.20472 CS -137 & G & 0.02 & 0.03 & PCI/G & $4 / 12 / 95$ \\
\hline $6211 \cdot-p$ & 94.20472 EU-152 & $\mathbf{G}$ & 1.97 & 0.52 & $\mathrm{PCl} / \mathrm{G}$ & $4 / 12 / 95$ \\
\hline $6211-p$ & $94.20472 \times-40$ & $G$ & 43.45 & 5.14 & $\mathrm{PCI} / \mathrm{G}$ & $4 / 12 / 95$ \\
\hline $6211-p$ & 94.20472 LA-140 & G & 0.0 & & $\mathrm{PCl} / \mathrm{G}$ & $4 / 12 / 95$ \\
\hline $6219-p$ & $94.20472 \mathrm{MK}-54$ & G & 0.04 & 0.06 & PCI/G & $4 / 12 / 95$ \\
\hline $6211-p$ & 94.20472 HA-22 & G & 0.08 & 0.12 & $\mathrm{PCI} / \mathrm{G}$ & $4 / 12 / 95$ \\
\hline $6211-p$ & $94.20472 \mathrm{KP}-237$ & 6 & 0.33 & 0.5 & $\mathrm{PCI} / \mathrm{G}$ & $4 / 12 / 95$ \\
\hline $6219-p$ & 94.20472 PA-231 & G & 0.14 & 0.21 & $\mathrm{PCl} / \mathrm{G}$ & $4 / 12 / 95$ \\
\hline $6211-P$ & 94.20472 PA-233 & G & 0.08 & 0.12 & $P C I / G$ & $4 / 12 / 95$ \\
\hline $6211-p$ & 94.20472 PB-210 & G & 0.0 & 2.7 & $\mathrm{PCl} / \mathrm{G}$ & $4 / 12 / 95$ \\
\hline $6211-p$ & 94.20472 PB-212 & G & 0.33 & 0.09 & $\mathrm{PCl} / \mathrm{G}$ & $4 / 12 / 95$ \\
\hline $6211-p$ & 94.20472 PB-214 & G & 0.39 & 0.1 & PCI/G & $4 / 12 / 95$ \\
\hline $6219-P$ & 94.20472 RA-223 & $\mathbf{G}$ & 4.61 & 6.92 & PCI/G & $4 / 12 / 95$ \\
\hline $6211-P$ & 94.20472 RA-224 & G & 0.84 & 1.26 & $\mathrm{PCI} / \mathrm{G}$ & $4 / 12 / 95$ \\
\hline $6211-p$ & 94.20472 RA-226 & G & 0.22 & 0.33 & PCI/G & $4 / 12 / 95$ \\
\hline $6211-p$ & 94.20472 RH-219 & $\mathbf{G}$ & 0.07 & 0.11 & $\mathrm{PCl} / \mathrm{G}$ & $4 / 12 / 95$ \\
\hline $6211-P$ & $94.20472 \mathrm{RU}-106$ & G & 0.34 & 0.51 & PCI/G & $4 / 12 / 95$ \\
\hline $6211-P$ & 94.20472 SE- 73 & G & 0.03 & 0.05 & $\mathrm{PCl} / \mathrm{G}$ & $4 / 12 / 95$ \\
\hline $6211-p$ & $94.20472 \mathrm{TL}-208$ & $G$ & 0.26 & 0.07 & $\mathrm{PCl} / \mathrm{G}$ & $4 / 12 / 95$ \\
\hline $6211-P$ & $94.204722 \mathrm{~N}-65$ & $G$ & 0.14 & 0.21 & $\mathrm{PCl} / \mathrm{G}$ & $4 / 12 / 95$ \\
\hline $6211-1 \mathrm{C}$ & $94.20473 B A-140$ & G & 0.0 & & $\mathrm{PCI} / \mathrm{G}$ & $4 / 12 / 95$ \\
\hline $6211-1 C$ & 94.20473 81-212 & G & 0.58 & 0.87 & PCI/G & $4 / 12 / 95$ \\
\hline $6211-10$ & $94.20473 \mathrm{B1}-214$ & $G$ & 0.41 & 0.13 & $\mathrm{PCI} / \mathrm{G}$ & $4 / 12 / 95$ \\
\hline $6211-1 c$ & 94.20473 CE- 144 & $G$ & 0.24 & 0.36 & $\mathrm{PCI} / \mathrm{G}$ & $4 / 12 / 95$ \\
\hline $6211-1 C$ & $94.20473 \mathrm{CO} .57$ & $\mathbf{G}$ & 0.05 & 0.02 & PCI/G & $4 / 12 / 95$ \\
\hline $6211-1 C$ & 94.2047360 .60 & G & 0.94 & 0.17 & $\mathrm{PCl} / \mathrm{G}$ & $4 / 12 / 95$ \\
\hline $6211-1 C$ & 94.20473 CS- 134 & G & 0.04 & 0.06 & PCI/G & $4 / 12 / 95$ \\
\hline $6211-1 C$ & 94.20473 Cs -137 & G & 0.04 & 0.06 & $\mathrm{PCI} / \mathrm{G}$ & $4 / 12 / 95$ \\
\hline $6211-1 c$ & 94.20473 EU- 152 & $\mathbf{G}$ & 2.24 & 0.55 & $\mathrm{PCI} / \mathrm{G}$ & $4 / 12 / 95$ \\
\hline $6219-1 c$ & $94.20473 \times-40$ & G & 50.15 & 5.78 & $\mathrm{PCl} / \mathrm{G}$ & $4 / 12 / 95$ \\
\hline $6211-1 c$ & 94.20473 LA- 140 & G & 0.0 & & $P C I / G$ & $4 / 12 / 95$ \\
\hline $6211-1 C$ & $94.20473 \mathrm{MN}-54$ & G & 0.02 & 0.03 & PCI/G & $4 / 12 / 95$ \\
\hline $6211-1 \mathrm{C}$ & 94.20473 HA-22 & G & 0.11 & 0.06 & $P C I / G$ & $4 / 12 / 95$ \\
\hline $6211-1 c$ & $94.20473 \mathrm{HP}-237$ & G & 0.25 & 0.38 & $\mathrm{PCI} / \mathrm{G}$ & $4 / 12 / 95$ \\
\hline $6211-10$ & 94.20473 PA-231 & G & 1.88 & 2.82 & $\mathrm{PCl} / \mathrm{G}$ & $4 / 12 / 95$ \\
\hline $6211-1 C$ & 94.20473 PA-233 & G & 0.0 & & $\mathrm{PCl} / \mathrm{G}$ & $4 / 12 / 95$ \\
\hline $6211-1 C$ & 94.20473 PB-210 & G & 0.0 & 2.7 & PCI/G & $4 / 12 / 95$ \\
\hline $6211-1 \mathrm{C}$ & 94.20473 РВ -212 & G & 0.23 & 0.07 & $\mathrm{PCl} / \mathrm{G}$ & $4 / 12 / 95$ \\
\hline $6211-1 C$ & 94.20473 PB-214 & $\mathbf{G}$ & 0.21 & 0.06 & $\mathrm{PCl} / \mathrm{G}$ & $4 / 12 / 95$ \\
\hline $6211-1 C$ & 94.20473 RA- 223 & $\mathbf{G}$ & 0.0 & & $P C I / G$ & $4 / 12 / 95$ \\
\hline $6211-1 c$ & $94.20473 \mathrm{RA}-224$ & G & 0.0 & 1.6 & $\mathrm{PCl} / \mathrm{G}$ & $4 / 12 / 95$ \\
\hline $6211 \cdot 1 C$ & $94.20473 \mathrm{RA}-226$ & a & 1.63 & 0.68 & $\mathrm{PCI} / \mathrm{G}$ & $4 / 12 / 95$ \\
\hline
\end{tabular}




\begin{tabular}{|c|c|c|c|c|c|c|c|}
\hline $6211-1 \mathrm{C}$ & 94.20473 & $\mathrm{RN}-219$ & G & 0.55 & 0.83 & PCI/G & $4 / 12 / 95$ \\
\hline $6211-1 c$ & 94.20473 & $R U-106$ & G & 0.09 & 0.14 & PCI/G & 4/12/95. \\
\hline $6211-1 c$ & 94.20473 & $S E-75$ & 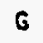 & 0.01 & 0.02 & PCl/G & $4 / 12 / 95$ \\
\hline $6211-1 c$ & 94.20473 & $\mathrm{TL}-208$ & $G$ & 0.22 & 0.07 & $\mathrm{PCl} / \mathrm{G}$ & $4 / 12 / 95$ \\
\hline $6219-1 c$ & 94.20473 & $2 \mathrm{~N}-65$ & $\sigma$ & 0.61 & 0.17 & PCI/G & $4 / 12 / 95$ \\
\hline $6211-2 C$ & 94.20474 & $B A-140$ & G & 9.79 & 14.69 & $\mathrm{PCl} / \mathrm{G}$ & $4 / 12 / 95$ \\
\hline $6211-2 c$ & 94.20474 & $81 \cdot 212$ & $G$ & 0.59 & 0.89 & $\mathrm{PCl} / \mathrm{G}$ & $4 / 12 / 95$ \\
\hline $6211-2 c$ & 94.20474 & $81-214$ & 0 & 0.72 & 0.16 & PCI/G & $4 / 12 / 95$ \\
\hline $6219-2 C$ & 94.20474 & CE-144 & $G$ & 0.4 & 0.6 & $\mathrm{PCl} / \mathrm{G}$ & $4 / 12 / 95$ \\
\hline $6211-2 c$ & 94.20474 & Co-57 & $\sigma$ & 0.1 & 0.03 & $P C I / G$ & 4/12/95 \\
\hline $6211-2 c$ & 94.20474 & $c 0-60$ & G & 1.01 & 0.15 & $\mathrm{PCI} / \mathrm{G}$ & $4 / 12 / 95$ \\
\hline $6211-2 C$ & 94.20474 & Cs-134 & 0 & 0.07 & 0.03 & $\mathrm{PCI} / \mathrm{G}$ & $4 / 12 / 95$ \\
\hline $6211-2 c$ & 94.20474 & Cs-137 & G & 0.04 & 0.06 & PCI/G & $4 / 12 / 95$ \\
\hline $6211-2 C$ & 94.20474 & EU-152 & G & 2.36 & 0.56 & PCI/G & 4/12/95 \\
\hline $6211 \cdot 2 C$ & 94.20474 & $k=40$ & $\sigma$ & 49.47 & 5.73 & $\mathrm{PCl} / \mathrm{G}$ & $4 / 12 / 95$ \\
\hline $6211-2 c$ & 94.20474 & $L A-140$ & G & 0.0 & & $\mathrm{PCl} / \mathrm{G}$ & $4 / 12 / 95$ \\
\hline $6211-2 C$ & 94.20474 & $M N-54$ & G & 0.01 & 0.02 & PCI/G & $4 / 12 / 95$ \\
\hline $6211-2 c$ & 94.20474 & MA-22 & 6 & 0.07 & 0.11 & $P C I / G$ & $4 / 12 / 95$ \\
\hline $6211-2 c$ & 94.20474 & NP-237 & G & 0.19 & 0.29 & PCI/G & $4 / 12 / 95$ \\
\hline $6211-2 c$ & 94.20474 & $P A-23 i$ & $\sigma$ & 2.76 & 4.14 & $\mathrm{PCl} / \mathrm{G}$ & $4 / 12 / 95$ \\
\hline $6211-2 c$ & 94.20474 & $P A-233$ & 6 & 0.38 & 0.57 & PCI/G & $4 / 12 / 95$ \\
\hline $6211-2 c$ & 94.20474 & $P B-210$ & G & 0.0 & 2.7 & $\mathrm{PCI} / \mathrm{G}$ & $4 / 12 / 95$ \\
\hline $6211-2 C$ & 94.20474 & $\mathrm{~PB}-212$ & $G$ & 0.09 & 0.14 & $\mathrm{PCl} / \mathrm{G}$ & $4 / 12 / 95$ \\
\hline $6211-2 c$ & 94.20474 & PB-214 & 0 & 0.17 & 0.08 & $\mathrm{PCl} / \mathrm{G}$ & 4/12/95 \\
\hline $6211-2 C$ & 94.20474 & $R A-223$ & 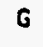 & 78.29 & 117.44 & PCI/G & $4 / 12 / 95$ \\
\hline $6211-2 C$ & 94.20474 & $R A-224$ & 6 & 0.02 & 0.03 & $\mathrm{PCl} / \mathrm{G}$ & $4 / 12 / 95$ \\
\hline $6211-2 C$ & 94.20474 & $R A-226$ & 0 & 0.39 & 0.59 & PCI/G & $4 / 12 / 95$ \\
\hline $6211-2 c$ & 94.20474 & $R H-219$ & G & 0.39 & 0.59 & $P C l / G$ & $4 / 12 / 95$ \\
\hline $6211-2 c$ & 94.20474 & $R U-106$ & 0 & 0.87 & 1.31 & $\mathrm{PCl} / \mathrm{G}$ & $4 / 12 / 95$ \\
\hline $6219-2 c$ & 94.20474 & $S E-T S$ & $G$ & 0.02 & 0.03 & $P C 1 / G$ & $4 / 12 / 95$ \\
\hline $6219-2 c$ & 94.20474 & $T L-208$ & G & 0.25 & 0.06 & PCI/G & $4 / 12 / 95$ \\
\hline $6211-2 c$ & 94.20474 & $2 N-65$ & G & 0.07 & 0.11 & $\mathrm{PCl} / \mathrm{G}$ & $4 / 12 / 95$ \\
\hline $6211-3 c$ & 94.20473 & $B A-140$ & 0 & 25.8 & 38.7 & PCI/G & 4/12/95 \\
\hline $6219-3 C$ & 94.20475 & $81-212$ & 6 & 0.75 & 1.13 & $\mathrm{PCI} / \mathrm{G}$ & $4 / 12 / 95$ \\
\hline $6211-3 C$ & 94.20475 & $81-214$ & G & 0.58 & 0.15 & PCI/G & $4 / 12 / 95$ \\
\hline $6211-3 c$ & 94.20475 & CE-144 & o & 0.28 & 0.42 & PCI/G & $4 / 12 / 95$ \\
\hline $6211-3 c$ & $94.204 \pi 5$ & $c 0-57$ & G & 0.1 & 0.03 & $\mathrm{PCl} / \mathrm{G}$ & $4 / 12 / 95$ \\
\hline $6211-3 c$ & 94.20475 & $10-60$ & 0 & 1.12 & 0.16 & $\mathrm{PCI} / \mathrm{G}$ & $4 / 12 / 95$ \\
\hline $6211-3 c$ & 94.20475 & CS-134 & G & 0.04 & 0.06 & PCI/G & 4/12/95 \\
\hline $6211-3 c$ & 94.20475 & cs-137 & 6 & 0.04 & 0.06 & PCI/G & $4 / 12 / 95$ \\
\hline $6211-3 c$ & 94.20475 & EU-152 & G & 2.66 & 0.63 & PCI/G & $4 / 12 / 95$ \\
\hline $6211-3 C$ & 94.20475 & $x-40$ & G & 47.19 & 5.5 & PCI/G & 4/12/95 \\
\hline $6211-3 c$ & 94.20475 & $L A-140$ & G & 0.0 & & PCI/G & $4 / 12 / 95$ \\
\hline $6219-3 c$ & 94.20473 & MN-54 & G & 0.02 & 0.03 & $\mathrm{PCl} / \mathrm{G}$ & $4 / 12 / 95$ \\
\hline $6211 \cdot 3 c$ & 94.20475 & HA-22 & G & 0.12 & 0.18 & PCI/G & 4/12/95 \\
\hline $6211-3 c$ & 94.20675 & NP-237 & G & 0.22 & 0.33 & $\mathrm{PCl} / \mathrm{G}$ & $4 / 12 / 95$ \\
\hline $6211-3 c$ & 94.20475 & $P A-239$ & G & 2.14 & 3.21 & PCI/G & 4/12/95 \\
\hline $6211-3 c$ & 94.20475 & $P A-233$ & G & 0.23 & 0.35 & PCI/G & 4/12/95 \\
\hline $6211-3 c$ & 94.20475 & PB-210 & G & 0.0 & 2.7 & $\mathrm{PCI} / \mathrm{G}$ & $4 / 12 / 95$ \\
\hline $6211-3 C$ & 94.20475 & $P B-212$ & G & 0.12 & 0.06 & $\mathrm{PCI} / \mathrm{G}$ & $4 / 12 / 95$ \\
\hline $6219-3 C$ & 94.20475 & PB-214 & G & 0.16 & 0.07 & $\mathrm{PCl} / \mathrm{G}$ & $4 / 12 / 95$ \\
\hline $6211-3 C$ & $94.204 \pi 3$ & $R A-223$ & G & 54.27 & 89.41 & PCI/G & $4 / 12 / 95$ \\
\hline $6211-3 c$ & 94.20475 & $R A-224$ & G & 0.98 & 1.47 & $\mathrm{PCI} / \mathrm{G}$ & $4 / 12 / 95$ \\
\hline $6211-3 c$ & 94.20475 & $R A-226$ & G & 1.68 & 0.64 & $\mathrm{PCl} / \mathrm{G}$ & $4 / 12 / 95$ \\
\hline $6219-3 c$ & 94.20475 & $R N-219$ & G & 0.45 & 0.68 & PCI/G & $4 / 12 / 95$ \\
\hline $6211-3 c$ & 94.20475 & $R U-106$ & G & 0.15 & 0.23 & PCI/G & $4 / 12 / 95$ \\
\hline $6211-3 c$ & 94.20475 & SE-75 & G & 0.17 & 0.26 & PCI/G & $4 / 12 / 95$ \\
\hline $6211-3 c$ & 94.20475 & $T L-208$ & 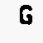 & 0.26 & 0.07 & $\mathrm{PCl} / \mathrm{G}$ & $4 / 12 / 95$ \\
\hline $6211-3 c$ & 94.20475 & $2 N-65$ & $G$ & 0.82 & 9.23 & $\mathrm{PCI} / \mathrm{G}$ & $4 / 12 / 95$ \\
\hline $6243-2 c$ & 94.20476 & $B A-140$ & G & 87.81 & 131.77 & perifr & $4 / 193105$ \\
\hline
\end{tabular}




\begin{tabular}{|c|c|c|c|c|c|c|}
\hline $6243-2 C$ & 94.20476 B1-212 & G & 0.41 & 0.62 & $P C l / G$ & $4 / 12 / 95$ \\
\hline $6243-2 C$ & 94.20476 B1-214 & 6 & 0.52 & 0.14 & PCI/G & $4 / 12 / 95$ \\
\hline $6243-2 C$ & 94.20476 CE-144 & G & 0.11 & 0.17 & $\mathrm{PCl} / \mathrm{G}$ & $4 / 12 / 95$ \\
\hline $6243-2 C$ & $94.20476 \mathrm{CO}-57$ & G & 0.08 & 0.03 & $P C l / G$ & $4 / 12 / 95$ \\
\hline $6243-2 C$ & $94.20476 \mathrm{CO}-60$ & G & 2.42 & 0.28 & $P C I / G$ & $4 / 12 / 95$ \\
\hline $6243-2 C$ & 94.20476 CS -134 & G & 0.13 & 0.05 & $\mathrm{PCl} / \mathrm{G}$ & $4 / 12 / 95$ \\
\hline $6243-2 C$ & 94.20476 CS 137 & G & 0.02 & 0.03 & $P C I / G$ & $4 / 12 / 95$ \\
\hline $6243 \cdot 2 C$ & 94.20476 EU-152 & G & 2.72 & 0.65 & $\mathrm{PCl} / \mathrm{G}$ & $4 / 12 / 95$ \\
\hline $6243-2 c$ & $94.20476 K-40$ & G & 46.52 & 5.48 & PCI/G & $4 / 12 / 95$ \\
\hline $6243-2 C$ & $94.20476 \mathrm{LA}-140$ & G & 0.0 & & $P C I / G$ & $4 / 12 / 95$ \\
\hline $6243-2 C$ & $94.20476 \mathrm{KH}-54$ & G & 0.07 & 0.11 & PCI/G & $4 / 12 / 95$ \\
\hline $6243-2 C$ & $94.20476 \mathrm{HA-22}$ & G & 0.11 & 0.17 & $\mathrm{PCI} / \mathrm{G}$ & $4 / 12 / 95$ \\
\hline $6243-2 C$ & $94.20476 \mathrm{HP}-237$ & G & 0.99 & 1.49 & PCI/G & $4 / 12 / 95$ \\
\hline $6243-2 C$ & $94.20476 \mathrm{PA}-231$ & G & 1.56 & 0.73 & PCI/G & $4 / 12 / 95$ \\
\hline $6243-2 C$ & 94.20476 PA-233 & G & 0.18 & 0.27 & $P C I / G$ & $4 / 12 / 95$ \\
\hline $6243-2 C$ & $94.20476 \mathrm{~PB}-210$ & G & 0.0 & 2.7 & $\mathrm{PCl} / \mathrm{G}$ & $4 / 12 / 95$ \\
\hline $6243-2 C$ & 94.20476 PB-212 & G & 0.12 & 0.06 & $P C I / G$ & $4 / 12 / 95$ \\
\hline $6243-2 C$ & 94.20476. PB-214 & G & 0.27 & 0.07 & PCI/G & $4 / 12 / 95$ \\
\hline $6243-2 C$ & $94.20476 R A-223$ & G & 38.53 & 57.8 & $P C I / G$ & $4 / 12 / 95$ \\
\hline $6243-2 C$ & $94.20476 \mathrm{RA}-224$ & $\mathbf{G}$ & 0.28 & 0.42 & $\mathrm{PCl} / \mathrm{G}$ & $4 / 12 / 95$ \\
\hline $6243-2 C$ & $94.20476 \mathrm{RA}-226$ & G & 0.47 & 0.79 & $P C I / G$ & $4 / 12 / 95$ \\
\hline $6243-2 C$ & 94.20476 RN-219 & G & 0.11 & 0.17 & $P C I / G$ & $4 / 12 / 95$ \\
\hline $6243-2 C$ & $94.20476 \mathrm{RU}-106$ & G & 1.34 & 2.01 & PCI/G & $4 / 12 / 95$ \\
\hline $6243-2 C$ & $94.20476 \mathrm{SE}-75$ & G & 0.04 & 0.06 & $P C I / G$ & $4 / 12 / 95$ \\
\hline $6243 \cdot 2 C$ & $94.20476 \mathrm{TL}-208$ & G & 0.22 & 0.06 & $\mathrm{PCl} / \mathrm{G}$ & $4 / 12 / 95$ \\
\hline $6243-2 C$ & $94.204762 \mathrm{H}-65$ & G & 1.34 & 2.01 & $\mathrm{PCI} / \mathrm{G}$ & $4 / 12 / 95$ \\
\hline $6243-3 c$ & $94.20477 \mathrm{BA}-140$ & G & 4.73 & 7.1 & $\mathrm{PCI} / \mathrm{G}$ & $4 / 12 / 95$ \\
\hline $6243-3 c$ & 94.20477 BI-212 & G & 0.52 & 0.78 & PCI/G & $4 / 12 / 95$ \\
\hline $6243-3 C$ & $94.2047781-214$ & G & 0.39 & 0.18 & $\mathrm{PCl} / \mathrm{G}$ & $4 / 12 / 95$ \\
\hline $6243-3 C$ & 94.20477 CE-144 & G & 0.08 & 0.12 & $\mathrm{PCl} / \mathrm{G}$ & $4 / 12 / 95$ \\
\hline $6243-3 C$ & $94.20477 \mathrm{CO}-57$ & G & 0.01 & 0.02 & $\mathrm{PCI} / \mathrm{G}$ & $4 / 12 / 95$ \\
\hline $6243-3 C$ & $94.20477 \mathrm{co-60}$ & G & 0.42 & 0.09 & PCI/G & $4 / 12 / 95$ \\
\hline $6243-3 C$ & 94.20477 CS -134 & G & 0.1 & 0.04 & $\mathrm{PCI} / \mathrm{G}$ & $4 / 12 / 95$ \\
\hline $6243 \cdot 3 c$ & 94.20477 cs -137 & G & 0.06 & 0.09 & $\mathrm{PCl} / \mathrm{G}$ & $4 / 12 / 95$ \\
\hline $6243 \cdot 3 C$ & 94.20477 EU-152 & G & 0.1 & 0.15 & $\mathrm{PCl} / \mathrm{G}$ & $4 / 12 / 95$ \\
\hline $6243-3 c$ & $94.20477 \times-40$ & G & 28.92 & 3.08 & PCI/G & $4 / 12 / 95$ \\
\hline $6243 \cdot 3 C$ & 94.20477 LA- 140 & G & 0.0 & & $\mathrm{PCl} / \mathrm{G}$ & $4 / 12 / 95$ \\
\hline $6243-3 c$ & 94.20477 MH-54 & G & 0.1 & 0.04 & $\mathrm{PCl} / \mathrm{G}$ & $4 / 12 / 95$ \\
\hline $6243-3 c$ & 94.20477 HА- 22 & G & 0.03 & 0.05 & $\mathrm{PCl} / \mathrm{G}$ & $4 / 12 / 95$ \\
\hline $6243-3 C$ & 94.20477 HP-237 & $\mathbf{G}$ & 0.16 & 0.24 & $\mathrm{PCl} / \mathrm{G}$ & $4 / 12 / 95$ \\
\hline $6243-3 c$ & 94.20477 PA-231 & 6 & 0.75 & 1.13 & $\mathrm{PCl} / \mathrm{G}$ & $4 / 12 / 95$ \\
\hline $6243-3 c$ & 94.20477 PA-233 & G & 1.4 & 0.93 & PCI/G & $4 / 12 / 95$ \\
\hline $6243 \cdot 3 C$ & 94.20477 PB-210 & G & 0.0 & 2.7 & $\mathrm{PCI} / \mathrm{G}$ & $4 / 12 / 95$ \\
\hline $6243-3 C$ & 94.20477 PB-212 & G & 0.14 & 0.08 & $\mathrm{PCI} / \mathrm{G}$ & $4 / 12 / 95$ \\
\hline $6243-3 c$ & 94.20477 PB-214 & G & 0.04 & 0.06 & $\mathrm{PCl} / \mathrm{G}$ & $4 / 12 / 95$ \\
\hline $6243-3 c$ & 94.20477 RA-223 & G & 13.38 & 20.07 & $\mathrm{PCl} / \mathrm{G}$ & $4 / 12 / 95$ \\
\hline $6243-3 C$ & 94.20477 RA-224 & 6 & 0.27 & 0.42 & $\mathrm{PCl} / \mathrm{G}$ & $4 / 12 / 95$ \\
\hline $6243-3 C$ & $94.20477 \mathrm{RA}-226$ & G & 9.69 & 0.65 & $\mathrm{PCI} / \mathrm{G}$ & $4 / 12 / 95$ \\
\hline $6243-3 c$ & 94.20477 RH-219 & G & 0.57 & 0.86 & $\mathrm{PCl} / \mathrm{G}$ & $4 / 12 / 95$ \\
\hline $6243-3 c$ & $94.20477 \mathrm{RU}-106$ & G & 0.45 & 0.68 & $\mathrm{PCl} / \mathrm{G}$ & $4 / 12 / 95$ \\
\hline $6243-3 c$ & 94.20477 SE-75 & G & 0.04 & 0.06 & PCI/G & $4 / 12 / 95$ \\
\hline $6243-3 C$ & $94.20477 \mathrm{TL}-208$ & $G$ & 0.16 & 0.06 & $\mathrm{PCl} / \mathrm{G}$ & $4 / 12 / 95$ \\
\hline $6243-3 C$ & $94.204772 k-65$ & G & 0.06 & 0.09 & $\mathrm{PCl} / \mathrm{G}$ & $4 / 12 / 95$ \\
\hline $6243 \cdot 1 \mathrm{C}$ & $94.20478 \mathrm{BA}-140$ & G & 40.6 & 29.67 & $\mathrm{PCl} / \mathrm{G}$ & $4 / 12 / 95$ \\
\hline $6243-1 C$ & 94.20478 BI-212 & $\mathbf{G}$ & 0.99 & 0.66 & $\mathrm{PCI} / \mathrm{G}$ & $4 / 12 / 95$ \\
\hline $6243-1 C$ & $94.20478 \mathrm{BI}-214$ & G & 0.3 & 0.14 & $\mathrm{PCl} / \mathrm{G}$ & $4 / 12 / 95$ \\
\hline $6243-1 C$ & 94.20478 CE- 144 & G & 0.07 & 0.11 & $\mathrm{PCI} / \mathrm{G}$ & $4 / 12 / 95$ \\
\hline $6243-1 C$ & $94.20478 \mathrm{co}-57$ & G & 0.01 & 0.02 & $\mathrm{PCl} / \mathrm{G}$ & $4 / 12 / 95$ \\
\hline $6243-10$ & $94.20478 \mathrm{Co.60}$ & G & 0.43 & 0.12 & $\mathrm{PCl} / \mathrm{G}$ & $4 / 12 / 95$ \\
\hline $6243-1 C$ & 94.20478 CS. 134 & G & 0.01 & 0.02 & $\mathrm{PCl} / \mathrm{G}$ & $4 / 12 / 95$ \\
\hline
\end{tabular}




\begin{tabular}{|c|c|c|c|c|c|c|c|}
\hline $6243-1 C$ & 94.20478 & CS- 137 & G & $\therefore .12$ & 0.05 & $\mathrm{PCl} / \mathrm{G}$ & $4 / 12 / 95$ \\
\hline $6243-1 C$ & 94.20478 & EU-152 & G & 0.17 & 0.26 & $\mathrm{PCI} / \mathrm{G}$ & $4 / 12 / 95$ \\
\hline $6243-1 C$ & 94.20478 & $x-40$ & $G$ & 22.58 & 2.7 & $\mathrm{PCl} / \mathrm{G}$ & $4 / 12 / 95$ \\
\hline $6243-1 C$ & 94.20478 & $L A-140$ & G & 0.0 & & $\mathrm{PCl} / \mathrm{G}$ & $4 / 12 / 95$ \\
\hline $6243-1 C$ & 94.20478 & MN-54 & G & 0.11 & 0.06 & $P C I / G$ & $4 / 12 / 95$ \\
\hline $6243-1 C$ & 94.20478 & NA-22 & $\mathbf{G}$ & 0.02 & 0.03 & $\mathrm{PCI} / \mathrm{G}$ & $4 / 12 / 95$ \\
\hline $6243-1 C$ & 94.20478 & NP- 237 & $G$ & 0.0 & 0.53 & $P C 1 / G$ & $4 / 12 / 95$ \\
\hline $6243 \cdot 1 C$ & 94.20478 & $P A-231$ & G & 1.98 & 2.97 & $P C I / G$ & $4 / 12 / 95$ \\
\hline $6243-1 C$ & 94.20478 & $P A-233$ & G & 2.32 & 0.71 & $\mathrm{PCl} / \mathrm{G}$ & $4 / 12 / 95$ \\
\hline $6243-1 C$ & 94.20478 & PB-210 & G & 0.0 & 2.7 & $P C l / G$ & $4 / 12 / 95$ \\
\hline $6243-1 C$ & 94.20478 & PB-212 & G & 0.08 & 0.05 & $\mathrm{PCI} / \mathrm{G}$ & $4 / 12 / 95$ \\
\hline $6243-1 C$ & 94.20478 & PB-214 & $\mathbf{G}$ & 0.1 & 0.05 & $P C I / G$ & $4 / 12 / 95$ \\
\hline $6243-1 C$ & 94.20478 & $R A-223$ & G & 0.0 & & $\mathrm{PCl} / \mathrm{G}$ & $4 / 12 / 95$ \\
\hline $6243-1 C$ & 94.20478 & $R A-224$ & G & 0.34 & 0.51 & $P C I / G$ & $4 / 12 / 95$ \\
\hline $6243-9 C$ & 94.20478 & $R A-226$ & $G$ & 3.42 & 0.78 & $\mathrm{PCl} / \mathrm{G}$ & $4 / 12 / 95$ \\
\hline $6243-1 C$ & 94.20478 & $R H-219$ & $\mathbf{G}$ & 0.62 & 0.47 & $\mathrm{PCI} / \mathrm{G}$ & $4 / 12 / 95$ \\
\hline $6243-1 C$ & 94.20478 & $R U-106$ & G & 1.04 & 0.6 & $P C I / G$ & $4 / 12 / 95$ \\
\hline $6243-1 C$ & 94.20478 & $S E-75$ & G & 0.0 & 1.5 & $\mathrm{PCl} / \mathrm{G}$ & $4 / 12 / 95$ \\
\hline $6243-1 c$ & 94.20478 & $T L-208$ & G & 0.17 & 0.06 & $\mathrm{PCI} / \mathrm{G}$ & $4 / 12 / 95$ \\
\hline $6243-1 C$ & 94.20478 & $2 N-65$ & G & 0.1 & 0.15 & $\mathrm{PCl} / \mathrm{G}$ & $4 / 12 / 95$ \\
\hline $6243-p$ & 94.20479 & $B A-140$ & G & 7.89 & 11.84 & $\mathrm{PCI} / \mathrm{G}$ & $4 / 12 / 95$ \\
\hline $6243-P$ & 94.20479 & BI-212 & G & 1.18 & 1.77 & $\mathrm{PCl} / \mathrm{G}$ & $4 / 12 / 95$ \\
\hline $6243-P$ & 94.20479 & BI-214 & G & 0.56 & 0.24 & $\mathrm{PCl} / \mathrm{G}$ & $4 / 12 / 95$ \\
\hline $6243-P$ & 94.20479 & CE-144 & G & 0.35 & 0.53 & $\mathrm{PCJ} / \mathrm{G}$ & $4 / 12 / 95$ \\
\hline $6243-P$ & 94.20479 & $c 0-57$ & G & 0.13 & 0.2 & $\mathrm{PCI} / \mathrm{G}$ & $4 / 12 / 95$ \\
\hline $6243-P$ & 94.20479 & $c 0-60$ & G & 1.28 & 0.28 & $\mathrm{PCl} / \mathrm{G}$ & $4 / 12 / 95$ \\
\hline $6243-P$ & 94.20479 & CS-134 & $\mathbf{G}$ & 0.0 & 0.15 & $\mathrm{PCl} / \mathrm{G}$ & $4 / 12 / 95$ \\
\hline $6243-P$ & 94.20479 & CS- 137 & $G$ & 0.02 & 0.03 & PCI/G & $4 / 12 / 95$ \\
\hline $6243-P$ & 94.20479 & EU-152 & $G$ & 0.03 & 0.05 & $\mathrm{PCl} / \mathrm{G}$ & $4 / 12 / 95$ \\
\hline $6243-p$ & 94.20479 & $x-40$ & $G$ & 529.19 & 40.64 & $P C l / G$ & $4 / 12 / 95$ \\
\hline $6243-P$ & 94.20479 & LA- 940 & $\mathbf{G}$ & 0.0 & & $P C I / G$ & $4 / 12 / 95$ \\
\hline $6243-P$ & 94.20479 & MN-54 & G & 0.01 & 0.02 & $\mathrm{PCI} / \mathrm{G}$ & $4 / 12 / 95$ \\
\hline $6243-P$ & 94.20479 & NA-22 & $G$ & 0.08 & 0.12 & $P C l / G$ & $4 / 12 / 95$ \\
\hline $6243-P$ & 94.20479 & HP- 237 & $G$ & 1.36 & 0.58 & $\mathrm{PCl} / \mathrm{G}$ & $4 / 12 / 95$ \\
\hline $6243-P$ & 94.20479 & $P A-231$ & G & 6.84 & 3.04 & $\mathrm{PCl} / \mathrm{G}$ & $4 / 12 / 95$ \\
\hline $6243-P$ & 94.20479 & PA-233 & G & 0.24 & 0.36 & $\mathrm{PCI} / \mathrm{G}$ & $4 / 12 / 95$ \\
\hline $6243-P$ & 94.20479 & PB-210 & G & 0.0 & 2.7 & PCI/G & $4 / 12 / 95$ \\
\hline $6243-P$ & 94.20479 & PB-212 & G & 0.01 & 0.02 & $P C I / G$ & $4 / 12 / 95$ \\
\hline $6243-P$ & 94.20479 & PB-214 & G & 0.22 & 0.33 & $\mathrm{PCI} / \mathrm{G}$ & $4 / 12 / 95$ \\
\hline $6243-P$ & 94.20479 & $R A-223$ & G & 3.17 & 4.76 & $\mathrm{PCl} / \mathrm{G}$ & $4 / 12 / 95$ \\
\hline $6243-P$ & 94.20479 & $R A-224$ & G & 0.35 & 0.53 & $P C I / G$ & $4 / 12 / 95$ \\
\hline $6243-P$ & 94.20479 & $R A-226$ & G & 3.63 & 1.58 & $P C I / G$ & $4 / 12 / 95$ \\
\hline $6243-P$ & 94.20479 & RH-219 & G & 0.84 & 1.26 & $P C l / G$ & $4 / 12 / 95$ \\
\hline $6243-P$ & 94.20479 & $R U-106$ & G & 0.77 & 1.16 & $\mathrm{PCl} / \mathrm{G}$ & $4 / 12 / 95$ \\
\hline $6243-P$ & 94.20479 & $S E-75$ & $\mathbf{G}$ & 0.0 & 9.5 & PCI/G & $4 / 12 / 95$ \\
\hline $6243-P$ & 94.20479 & $T L \cdot 208$ & G & 0.33 & 0.11 & $P C I / G$ & $4 / 12 / 95$ \\
\hline $6243-P$ & 94.20479 & $2 N-65$ & $\mathbf{G}$ & 0.29 & 0.435 & PCI/G & $4 / 12 / 95$ \\
\hline
\end{tabular}

